\title{
Article \\ A Green Nanostructured Pesticide to Control Tomato Bacterial Speck Disease
}

\author{
Daniele Schiavi $^{1, *(\mathbb{D})}$, Rosa Balbi ${ }^{2}$, Stefano Giovagnoli ${ }^{2}\left(\mathbb{D}\right.$, Emidio Camaioni $^{2}\left(\mathbb{D}\right.$, Ermelinda Botticella $^{1,3}$, \\ Francesco Sestili ${ }^{1}$ (D) and Giorgio Mariano Balestra ${ }^{1, *(D)}$ \\ 1 Department of Agricultural and Forestry Sciences (DAFNE), University of Tuscia, Via San Camillo de \\ Lellis snc, 01100 Viterbo, Italy; ermelinda.botticella@ispa.cnr.it (E.B.); francescosestili@unitus.it (F.S.) \\ 2 Department of Pharmaceutical Sciences (DSF), University of Perugia, Via del Liceo 1, 06123 Perugia, Italy; \\ rosa.balbi@hotmail.it (R.B.); stefano.giovagnoli@unipg.it (S.G.); emidio.camaioni@unipg.it (E.C.) \\ 3 CNR-Institute of Sciences of Food Production (ISPA), Unit of Lecce, Via Provinciale Lecce-Monteroni, \\ 73100 Lecce, Italy \\ * Correspondence: schiavi@unitus.it (D.S.); balestra@unitus.it (G.M.B.)
}

Citation: Schiavi, D.; Balbi, R.; Giovagnoli, S.; Camaioni, E.; Botticella, E.; Sestili, F.; Balestra, G.M. A Green Nanostructured Pesticide to Control Tomato Bacterial Speck Disease. Nanomaterials 2021, 11, 1852. https://doi.org/10.3390/nano 11071852

Academic Editor: Raffaele Riccò

Received: 11 June 2021

Accepted: 15 July 2021

Published: 18 July 2021

Publisher's Note: MDPI stays neutral with regard to jurisdictional claims in published maps and institutional affiliations.

Copyright: (C) 2021 by the authors. Licensee MDPI, Basel, Switzerland. This article is an open access article distributed under the terms and conditions of the Creative Commons Attribution (CC BY) license (https:/ / creativecommons.org/licenses/by/ $4.0 /)$.

\begin{abstract}
Bacterial speck disease, caused by Pseudomonas syringae pv. tomato (Pst), is one of the most pervasive biological adversities in tomato cultivation, in both industrial and in table varieties. In this work synthesis, biochemical and antibacterial properties of a novel organic nanostructured pesticide composed of chitosan hydrochloride $(\mathrm{CH})$ as active ingredient, cellulose nanocrystals (CNC) as nanocarriers and starch as excipient were evaluated. In order to study the possibility of delivering $\mathrm{CH}$, the effects of two different types of starches, extracted from a high amylose bread wheat (high amylose starch—HA Starch) and from a control genotype (standard starch—St Starch), were investigated. Nanostructured microparticles (NMP) were obtained through the spray-drying technique, revealing a $\mathrm{CH}$ loading capacity proximal to $50 \%$, with a $\mathrm{CH}$ release of $30 \%$ for $\mathrm{CH}-$ CNC-St Starch NMP and 50\% for CH-CNC-HA Starch NMP after $24 \mathrm{~h}$. Both NMP were able to inhibit bacterial growth in vitro when used at $1 \% \mathrm{w} / \mathrm{v}$. Moreover, no negative effects on vegetative growth were recorded when NMP were foliar applied on tomato plants. Proposed nanostructured pesticides showed the capability of diminishing Pst epiphytical survival during time, decreasing disease incidence and severity (from $45 \%$ to $49 \%$ ), with results comparable to one of the most used cupric salt (hydroxide), pointing out the potential use of $\mathrm{CH}-\mathrm{CNC}$-Starch NMP as a sustainable and innovative ally in Pst control strategies.
\end{abstract}

Keywords: cellulose nanocrystals; chitosan hydrochloride; starch; pseudomonas syringae pv. tomato; tomato; nanotechnology; microparticles; spray-drying; organic plant protection

\section{Introduction}

Recent advances in nanotechnology have shown the concrete possibility of minimizing agrochemicals used in agriculture, especially those ones related to plant protection strategies [1]. The greatest risks deriving from the abnormal application of traditional pesticides are manly linked to environmental pollution, due to the low effectiveness of compound delivery. Nanomaterials and nanofunctionalized carriers could provide a better coverage when applied on crops, enhancing antimicrobial properties of pesticides thanks to controlled release of active ingredients, and at the same time reducing the chemical dispersion in soil and waters [2,3]. Besides, today a more sustainable agriculture is strongly requested in those supply chains where the use of traditional pesticides such as cupric salts is discouraged. In the current scenario, the aim of the present work was to investigate the potential use of a novel green pesticide on one of the most widespread crop all over the world (tomato) and on one of its most commonly associated disease (bacterial speck). Bacterial speck is known for being able to infect both table and industrial varieties of tomato. This disease is provoked by the Gram negative bacteria Pseudomonas syringae pv. tomato 
(Pst), which is able to produce symptoms on fruits, leaves and stems. Bacterial cells from the epiphytic phase can penetrate living tissue through stomata or microlesions aroused by leaves pruning and harvesting operations, but also by environmental agents, such as wind, hail or rain, causing the appearance of chlorotic specks that necrotize quickly [4,5]. Necrotic tissues can merge together, leading to a loss of photosynthetic efficiency in green organs and the presence of scars, which compromises fruit's marketability. Moreover, the bacteria can survive on seeds, representing a huge threat in every tomato cultivation phase, from nursery to field [6]. Although the experimental application of alternative compounds has shown the potential capability of counteracting bacterial speck, nowadays tomato protection strategies still rely on the use of copper as a preventive tool to avoid bacterial infection and evasion [7-9]. Copper and its derivatives are well-known active principles for their antimicrobial activity against bacteria and fungi, ease of use and affordability, and due to that they are some of the most used worldwide $[10,11]$. On the other hand, several scientific studies highlighted the side effects of overusing copper in agriculture, including a negative impact on soil and water microorganisms and the appearance of resistant strains [12-15]. Governments are enacting different legislative measures in order to diminish the amount of usable copper in agriculture: in Europe, the European Commission, with the application of the executive regulation 2018/1981 of 13 December 2018, cut the maximum limit of usable copper from $6 \mathrm{~kg}$ per hectare per year (maximum $30 \mathrm{~kg}$ per hectare in five years) to $4 \mathrm{~kg}$ per hectare per year (maximum $28 \mathrm{~kg}$ per hectare in seven years), renewing the approval of the active substances copper compounds as candidates for substitution. The need to find alternative plant protection compounds in order to support farmers in plant protection strategies is mandatory. Several studies have already demonstrated the potential application of natural derived substances, such as phenols and essential oils, for controlling tomato bacterial diseases. Quattrucci et al. (2013) positively tested in vitro and in vivo the antimicrobial effects of Punica granatum peel extracts on Pst [16]. Morin, naringenin and phloretin, which are plant flavonoids, affect different Pst strains' virulence, reducing flagellin production and disturbing cell swimming and swarming motility [17]. Ethanolic extract of Magnolia tamaulipana was able to inhibit almost $90 \%$ of Pst growth at concentration of $125 \mathrm{ppm}$, while a strong in vitro antibacterial activity of essential oils extracted from different plants such as mint, thyme and eucalyptus was recorded on Pst, due to the presence of phenolic compounds [18,19]. Chitosan and its derivatives are some of the most studied antimicrobial compounds, the application of which in agriculture is already allowed as resistance inductors [20,21]. Due to its antifungal, antibacterial and antioxidant properties, together with its ability of boosting plants defenses and biological parameters, such as photosynthetic activity, seeds germination and vegetative growth, Chitosan is nowadays one of the most promising allies in sustainable plant protection strategies, from seed coating to post-harvest [22-26]. Moreover, the application of chitosan is being pursued due to its economic convenience, since it can be obtained from agroindustrial wastes, like seafood shells, which currently represent, unlike the aforementioned substances, a very affordable starting point in defining innovative crop protection compounds $[27,28]$. Several scientific publications highlight the promising use of chitosan in tomato fungal (Fusarium wilt) and bacterial (bacterial spot and wilt) diseases management, showing good effects on vegetative parameters of plants [29-32]. Mansilla et al. (2013) demonstrated antimicrobial properties of chitosan on Pst, suggesting that inhibition could depend on several chemical parameters ( $\mathrm{pH}$, presence of metal ions, concentration), while the mode of action could be related to cell membrane interaction [33]. Biological properties of different chitosan forms mainly depend on acetylation degree, molecular weight, viscosity and concentration. Among the different forms of chitosan, the hydrochloride one, which was used in this study, derives from the interaction of chitin with hydrochloric acid, bestowing a greater hydrophilicity [34-36]. The issue with an effective use of chitosan and other natural molecules on plants is linked to their tricky miscibility, chemical instability and hard-to-control release. In this way, nanotechnology could represent a great breakthrough in sustainable pesticide formulation $[2,37,38]$. Antimicrobial and resistance inductance 
properties of several nanoparticles synthetized from inorganic materials, such as zinc, copper, magnesium, silver, silica and graphene, were already positively assayed against tomato bacterial spot and speck diseases [39-43]. Furthermore, many materials can be engineered to obtain carriers at the nanoscale level, which can be functionalized with active principles. In this sense, a very effective low-cost solution is represented by organic polymers [44-46]. Among these, cellulose nanocrystals (CNC) are some of the most promising, due to their well-known biochemical properties, including high elasticity modulus, thermal stability, no cytotoxic effects and high presence of hydroxyls groups, which can be exploited for active principles linking [47-50]. Cortesi et al. (2017) showed how natural substances like gallic acid can be encapsulated in cellulose microparticles and effectively used against bacterial speck agents, while in other works antimicrobial properties on Pst were demonstrated in polymeric films derived from the combination of CNC with poly (lactic acid) [51,52]. Additionally, Fortunati et al. (2016) assessed the potential use of CNC as novel nanocarriers for smart delivery systems after proving their biocompatibility on tomato plants [53]. In order to grant controlled release features, starch was also considered as an additive. Starch and different starch-based nanostructures are well-known excipients, frequently used in the food and pharmaceutical industries [54]. Starch can facilitate the passage in solution of molecules by adsorbing water. This ability is influenced by the content of amylose (linear glucose polymer) and amylopectin (branched glucose polymer), which are normally present in a 1:3 ratio, as well as the variable architecture of the starch matrix. Starch with a high amylose content (HA Starch) has a better film forming ability and a higher gelling strength compared to standard starch (St Starch) [55,56]. Depending on origin and structure, HA Starch shows useful properties in terms of modulation of active substance release, and its crosslinked forms are common excipients $\left(\right.$ Contramid $\left.^{\circledR}\right)$ in oral formulations $[57,58]$. With the aim of improving human nutrition, research is currently starting to focus on obtaining high amylose content wheat genotypes [59].

In this work, we evaluated the possibility of fabricating a novel ternary delivery system by the spray-draying technique, using CNC as nanocarriers for chitosan hydrochloride $(\mathrm{CH})$, with the addition of standard starch or high amylose starch as possible release modifiers. Obtained nanostructured microparticles (NMP) were characterized for their biochemical properties, including effects on bacterial and plant growth in comparison with copper. To the best of our knowledge, this is the first time that a fully organic nanostructured pesticide is produced for the specific management of tomato bacterial speck disease.

\section{Materials and Methods}

\subsection{Materials}

Chitosan hydrochloride (CAS No. 70694-72-3) was purchased at Wuhan Victory Excellence Pharmaceutical Co., Ltd. (Wuhan, China). Microcrystalline cellulose (CAS No. 9004-34-6) was purchased at Sigma-Aldrich, Inc. (Taufkirchen, Germany) Standard starch and high amylose starch were extracted from the cultivar Cadenza and Cadenza SBEIIa, respectively. This latter line was recently produced by Botticella et al. (2018) through the silencing of a key gene involved in starch biosynthesis, the starch brancing enzyme of class IIa (SBEIIa) [60]. All other reagents used in this work were supplied by Sigma-Aldrich, Inc. (Taufkirchen, Germany), and used without further modifications.

\subsection{CNC Synthesis and Characterization}

\subsubsection{CNC Synthesis}

Cellulose nanocrystals (CNC) were synthetized by acid hydrolysis, as described by Cranston and Gray (2006) [61]. Microcrystalline cellulose was briefly hydrolyzed in a sulphuric acid solution $(64 \% \mathrm{w} / \mathrm{w})$ under continuous stirring at $45^{\circ} \mathrm{C}$ for $30 \mathrm{~min}$. The obtained suspension was put in dialysis tubes until the $\mathrm{pH}$ reached 7 . After that, $\mathrm{CNC}$ aqueous suspension went through an ultrasonic treatment ( $700 \mathrm{~W}$ for eight minutes). CNC were conserved at $4{ }^{\circ} \mathrm{C}$. 


\subsubsection{CNC Morphological and Chemical Characterization}

Acid hydrolysis yield was calculated using the method reported as UNI EN ISO 638:2009.

CNC morphology was investigated by field-emission microscope Zeiss LEO 1525 equipped with a GEMINI column (Oberkochen, Germany). Samples for SEM analysis were prepared by depositing CNC suspensions onto an aluminum specimen stub covered with a double-sided adhesive disc. The sample was coated with a chromium layer $(8 \mathrm{~nm}$ thickness) before imaging (Quorum Q150T ES East Grinstead, West Sussex, UK).

Absorption attenuated total reflection (ATR-IR) spectra were recorded with the Infrared Spectrophotometer IRSpirit (Shimadzu, Japan) in the spectral range of 400-5000 $\mathrm{cm}^{-1}$. The analyses were performed directly on the powders with no sample processing. Background spectra were acquired on the empty cell.

\subsection{Starch Extraction and Characterization}

\subsubsection{Starch Extraction}

Starch granules were extracted from whole flour using the dough ball method as described in Botticella et al. (2018) [60]. Ten grams of whole flour were mixed with 0.6 parts $(\mathrm{w} / \mathrm{w})$ of water, and kneaded to form a dough. Starch was washed from the dough with $300 \mathrm{~mL}$ deionized water until the washing water was clear. After a centrifugation at $1500 \times g$, the pellet was rinsed twice in $20 \mathrm{~mL}$ deionized water. The upper yellow-gray layer deposited on the surface of the starch pellet was manually removed with a spatula, and the starch left to dry for two days at room temperature.

\subsubsection{Starch Granule Morphology}

The morphology of starch granules was analyzed using a scanning electron microscopy (SEM) Hitachi S-4000 (Krefeld, Germany), as reported by Sparla et al. (2014) [62].

\subsubsection{Quantification of Amylose, Total Starch and Resistant Starch}

Amylose content was determined from $15 \mathrm{mg}$ aliquot of purified starch through a colorimetric assay based on an iodine-amylose reaction [63]. A standard curve was generated from mixtures of potato amylose (Fluka, Neu-Ulm, Germany) and wheat amylopectin (Sigma Aldrich, St. Louis, MO, USA). Total starch and resistant starch were determined from whole flour samples, using the Total Starch (AA/AMG) test and Resistant Starch Assay kits (Megazyme, Irishtown, Ireland). For the determination of the total starch content, the protocol specified for "samples containing also resistant starch" was followed.

For each analysis, three biological samples, each with three technical replicates, were measured either for Cadenza or Cadenza SBEIIa.

\subsection{Preliminary In Vitro Antibacterial Activity}

In order to define the most effective $\mathrm{CH}$ antibacterial concentration useful to assess the starting requirements for NMP preparation and in vivo application, as well as to investigate possible St Starch, HA Starch, and CNC antimicrobial effect, an in vitro assay was conducted.

\section{Agar Incorporation Assay}

Antimicrobial effects of substances were recorded using an agar incorporation method [64]. Pst (CFBP 1323) was grown on King's B (KB) medium plates at $27^{\circ} \mathrm{C}$ for $48 \mathrm{~h}$ [65]. Formed colonies were scraped off and suspended in deionized sterilized water to $10^{8} \mathrm{CFU} \mathrm{mL} \mathrm{mL}^{-1}$. Concentration of bacterial suspension was adjusted until an OD600 $=1$ was reached using a spectrophotometer [66]. A bacterial suspension of $104 \mathrm{CFU} \mathrm{mL}^{-1}$ was made. $\mathrm{KB}$ medium plates were amended with the different substances to reach $0.05,0.1,0.5$ and $1 \% \mathrm{w} / \mathrm{v}$ concentrations. KB medium was used as negative control, while copper hydroxide at $0.09 \% \mathrm{w} / \mathrm{v}$ (field dose) was used alone as a positive control [67]. Plates have been allowed to cool, and then $100 \mu \mathrm{L}$ of the bacterial suspension were gently plated on. After incubation at $27^{\circ} \mathrm{C}$ for $48 \mathrm{~h}$, formed colonies were counted using a stereomicroscope. Three replicates 
were made for each thesis. Minimal inhibitory concentration (MIC) of tested substances has been identified as the one where no visible colonies have grown, and so where inhibition percentage was equal to $100 \%$. Inhibition of bacterial growth was expressed as a percentage, and calculated below:

Inhibition $(\%)=\left[(\right.$ Neg. ctrl. abs.- Tested substance abs. $) \times$ Neg. ctrl. abs. $\left.^{-1}\right] \times 100$

\subsection{Synthesis and Charachterization of $\mathrm{CH}$-CNC-Starch NMP}

\subsubsection{Preparation and Characterization of CH-CNC-Starch NMP}

An established amount of CNC was suspended in ultrapure water to obtain a concentration of $15 \mathrm{mg} / \mathrm{mL}$. CH and St Starch or HA Starch were dissolved in the CNC suspension at 50:30:20 CH:CNC:Starch w/w ratio. The suspensions were then nebulized by a Büchi mini spray-dryer B-290 (Büchi ${ }^{\circledR}$, Flawil, Switzerland) in the following conditions: inlet temperature $140{ }^{\circ} \mathrm{C}$; aspirator rate $50 \%$; feed rate $2.4 \mathrm{~mL} / \mathrm{min}$; and air pressure $357 \mathrm{~L} / \mathrm{h}$. The powders were recovered and stored at room temperature and $30 \%$ relative humidity until use.

NMP morphology and IR spectroscopy analyses were performed on the powders according to the methods and conditions in paragraph 2.2.2.

In vitro release of $\mathrm{CH}$ from $\mathrm{CH}-\mathrm{CNC}$-Starch NMP was performed in PBS buffer $0.05 \mathrm{M}$ $\mathrm{pH} 7$ at $37^{\circ} \mathrm{C}$. The experiment was carried out in $50 \mathrm{~mL}$ falcon tubes. At established time points, an aliquot of $0.5 \mathrm{~mL}$ of PBS was collected and immediately replaced with the same volume of fresh PBS maintained at the same temperature. The amount of $\mathrm{CH}$ released was measured in triplicate by UV/Vis spectroscopy as reported above. The percent incremental release from the MP was plotted as a function of the incubation time. The experiment was run in triplicate, and data was reported as mean \pm S.D.

\subsubsection{CH Quantification Assay}

$\mathrm{CH}$ standard solutions were prepared as follows. A $\mathrm{CH}$ solution was pipetted into test tube, and $0.1 \mathrm{~mL}$ of $0.5 \mathrm{M} \mathrm{NaNO}_{2}$ reagent was added. The mixture was then incubated at $80{ }^{\circ} \mathrm{C}$ for $30 \mathrm{~min}$ in a water bath to complete the depolymerization-deamination reaction. After depolymerization, the $\mathrm{pH}$ was raised to 8 by adding $0.2 \mathrm{~mL} \mathrm{NaOH}(0.1 \mathrm{M})$, and the solution was then shaken. Subsequently, $1 \mathrm{~mL}$ of dinitrosalicylic acid reagent (DNSA, HiMedia), prepared as reported elsewhere [68], was added to the reaction mixtures, and the tubes were placed in a water bath at $75{ }^{\circ} \mathrm{C}$ for $15 \mathrm{~min}$. The solution was briefly cooled, and the absorbance was measured at $540 \mathrm{~nm}$ by an Agilent 8453 diode array spectrophotometer (Agilent, Milan, Italy) against blank. A standard curve was built in the range $0.1-1 \mathrm{mg} / \mathrm{mL}$ $\left(r^{2}=0.999\right)$.

\subsubsection{CH Extraction}

The $\mathrm{CH}$ content $(\% \mathrm{CC} \mathrm{w} / \mathrm{w})$ in the $\mathrm{CH}-\mathrm{CNC}$-Starch NMP formulations was performed by dispersing an exactly weighed amount of NMP in $0.1 \mathrm{M}$ acetic acid solution. The solution was incubated for $1 \mathrm{~h}$ at r.t. and periodically sonicated and vortexed, then treated according to the method for chitosan quantitation. All analyses were performed in triplicate, and the results expressed as mean \pm standard deviation (SD).

\subsubsection{NMP In Vitro Antibacterial Activity}

Antimicrobial effects of obtained NMP with different starches were recorded using a microdilution method $[69,70]$. A bacterial suspension of $10^{6} \mathrm{CFU} \mathrm{mL}^{-1}$ was made, after Pst was grown on KB medium at $27{ }^{\circ} \mathrm{C}$ for $48 \mathrm{~h}$. Dilutions at $0.05,0.1,0.5$ and $1 \% \mathrm{w} / \mathrm{v}$ were made for each NMP with LB broth. $198 \mu \mathrm{L}$ of each dilution were pipetted in well of a 96 multiwell microplate. Then, $2 \mu \mathrm{L}$ was of the bacterial suspension was added. LB broth was used as negative control, while copper hydroxide at field dose was used as positive control. For each thesis, a blank was made using only substances. Plates were incubated at $27{ }^{\circ} \mathrm{C}$ for $72 \mathrm{~h}$. In order to study the possible bacteriostatic and bactericidal effects of 
NMP on Pst and their trend over time, at 48 and $72 \mathrm{~h}$ absorbance of plates at $600 \mathrm{~nm}$ was measured using a spectrophotometer. MIC has been identified as the one where inhibition percentage was equal to $100 \%$. Inhibition of bacterial growth was expressed as a percentage, and calculated as below after subtracting the blank:

$$
\text { Inhibition }(\%)=\left[(\text { Neg. ctrl. abs.-Tested substance abs. }) \times \text { Neg. ctrl. abs. }{ }^{-1}\right] \times 100
$$

where NMP shown a full inhibition of Pst growth, $100 \mu \mathrm{L}$ from well were plated on a KB plate to assess the eventual bactericidal effects. Minimal bactericidal concentration (MBC) was defined as the one in which no colonies were recovered in plates after an incubation at $27^{\circ} \mathrm{C}$ for $48 \mathrm{~h}$. Eight replicates were made for each thesis.

\subsection{CH-CNC-Starch NMP Phytobiological Compatibility}

Obtained NMP were tested in vivo to assess their biocompatibility with living plant tissues. For each thesis, ten tomato seedlings of a local cultivar (San Marzano Scatolone) were picked up from an organic plant nursery, and have been acclimatized in a greenhouse with $75 \%$ air humidity, a $25 / 15^{\circ} \mathrm{C}$ day/night thermoperiod and a $16 / 8$ day/night photoperiod. Applied concentration of NMP was determined on results of antibacterial in vitro and quantification of loaded $\mathrm{CH}$ on NMP assays, as shown in the Result and Discussion paragraph. Two suspensions at $1 \% \mathrm{w} / \mathrm{v}$ were made with the two different NMP and sprayed manually all over the leaves and the stems, until a uniform coating was reached. Deionized sterilized water and copper hydroxide were used as controls. One, seven and fourteen days post-treatment $(1,7,14 \mathrm{dpt})$, the following parameters were recorded as stated for each thesis: three random leaves per plant were picked up and their area was measured with the software ImageJ (version 1.51j8) (NIH, Bethesda, MD, USA) (accessed on Windows 10) (Microsoft, Redmond, WA, USA) [71]; three measurements were made for each plant on the second leaf to assess the chlorophyll and flavonols content, and afterwards the nitrogen balance index (NBI), by a non-destructive method, using a leafclip sensor (Dualex 4 Scientific, FORCE-A, Orsay Cedex, France) $[67,72]$. The experiment was repeated thrice.

\subsection{In Vivo Antibacterial Activity}

In order to investigate the effect of the synthetized NMP on the disease development in a plant, an in vivo assay was performed. Ten tomato seedlings for each thesis were collected and treated as described in paragraph 2.6. $24 \mathrm{~h}$ after treatments, a $10^{6} \mathrm{CFU} \mathrm{mL}^{-1}$ Pst water-suspension was obtained after the bacteria was grown on KB medium for $48 \mathrm{~h}$ at $27^{\circ} \mathrm{C}$, and homogeneously spray-inoculated on leaves and stems. Plastic bags were placed on plants one day before and after the inoculation to increase the air humidity and promote the stomata's opening [67]. The experiment was repeated thrice.

\subsubsection{Bacterial Epiphytic Survival}

The effect of the NMP on Pst epiphytic survival was monitored one, seven and fourteen days post-inoculation $(1,7,14 \mathrm{dpi})$. Three random leaves per plants were collected and washed in a sterile plastic bag with a $\mathrm{pH} 7$ phosphate buffer $0.05 \mathrm{M}$ using a homogenizer (Stomacher 400 Circulator, Seward Ltd., Worthing, UK) set at $110 \mathrm{rpm}$ for $30 \mathrm{~s}$. For each sample, serial decimal dilutions were obtained, and a $100 \mu \mathrm{L}$ aliquot was gently plated on sucrose nutritive agar dishes. Each dilution was plated three times and incubated a $27^{\circ} \mathrm{C}$ for $48 \mathrm{~h}$. After that, developed bacterial colonies were counted and divided for the tomato leaf area measured with ImageJ; results were expressed as CFU $\mathrm{cm}^{-2}$ [67].

\subsubsection{Disease Symptomatic Expression}

Symptomatic expression of bacterial speck disease was monitored on leaves for the entire duration of the trial. Disease severity (DS) was calculated as the number of pointlike necrosis per plant at $7 \mathrm{dpi}$. Proportional disease reduction per plant (DR) was also calculated as below: 
Proportional disease reduction $(\%)=\left[(\right.$ Neg. ctrl. DS-Tested substance DS $) \times$ Neg. ctrl. DS $\left.{ }^{-1}\right] \times 100$

Disease incidence (DI) was calculated for each thesis at 7 and $14 \mathrm{dpi}$ as the percentage ratio between total symptomatic (necrotized) area and total area of the collected leaves for the assessment of Pst epiphytic survival [67].

\subsection{Statistical Analysis}

Collected data were analyzed using one-way analysis of variance (ANOVA). Statistical significance of means was studied with Tukey's HSD post hoc test. $p$-values less than 0.05 were considered significant, while $p$-values of less than 0.01 were considered highly significant. Release data were analyzed by paired Student's $t$-test at $95 \%$ significance level.

\section{Results and Discussion}

\subsection{CNC Synthesis and Characterization}

CNC were successfully obtained through acid hydrolysis of microcrystalline cellulose with a total yield of about $20 \%$. The method performance was consistent with relevant literature. SEM images show the typical needle shape of CNC with a certain homogeneity in size (Figure 1). The CNC IR spectral profile showed all the typical signals of CNC with no major changes compared to standard profiles. This excluded potential degradation effects of the harsh extraction conditions employed.

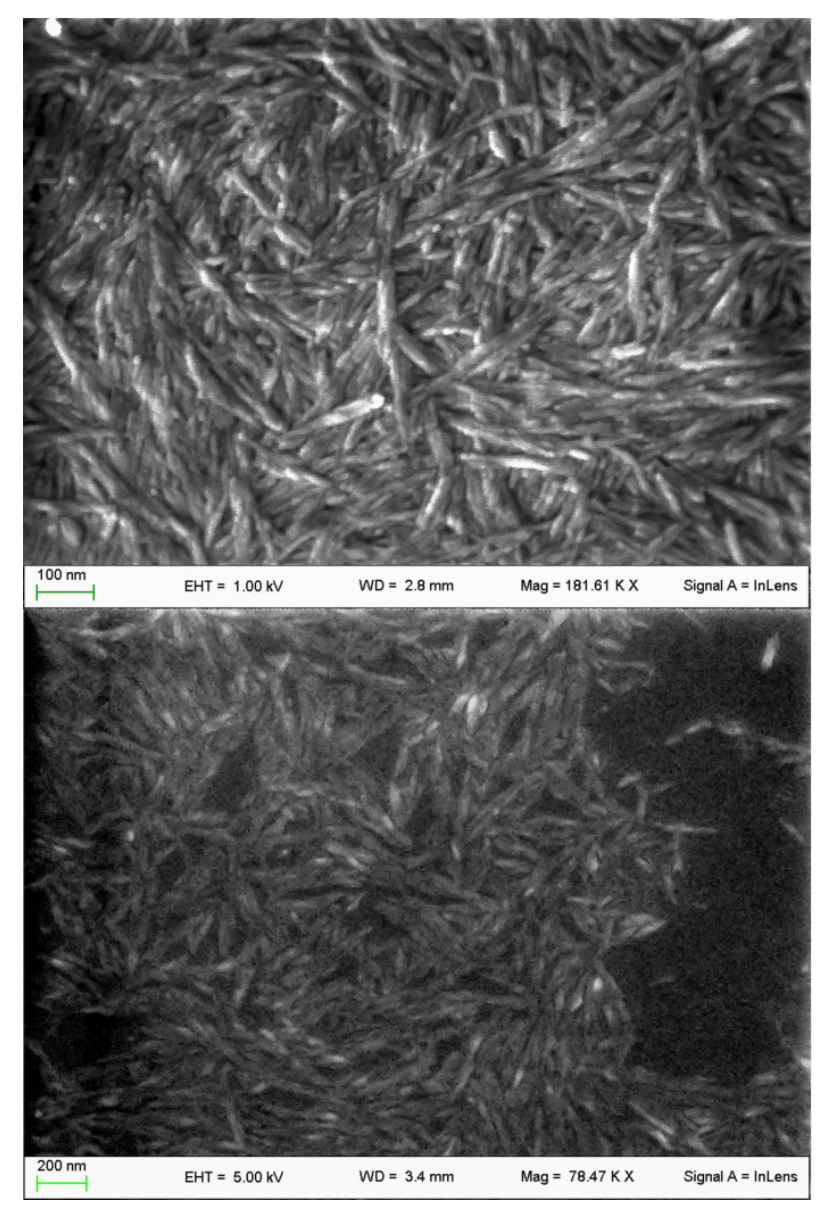

Figure 1. SEM microphotographs of the obtained CNC. Evident the typical elongated structure of nanocrystals and homogeneous size. Images were recorded at 78 (below) and 180 (above) kX. 


\subsection{ST Extraction and Characterization}

Morphological analysis of starch granules highlighted marked differences between Cadenza and Cadenza SBEIIa (Figure 2). In this latter genotype, type-A granules appeared deformed and deflated (Figure 2b) compared to the control (Figure 2a). Different type-B granules appeared more abundant, lost their normal spherical shape and became extended. Similar results were also observed by Botticella et al. (2018) [60].
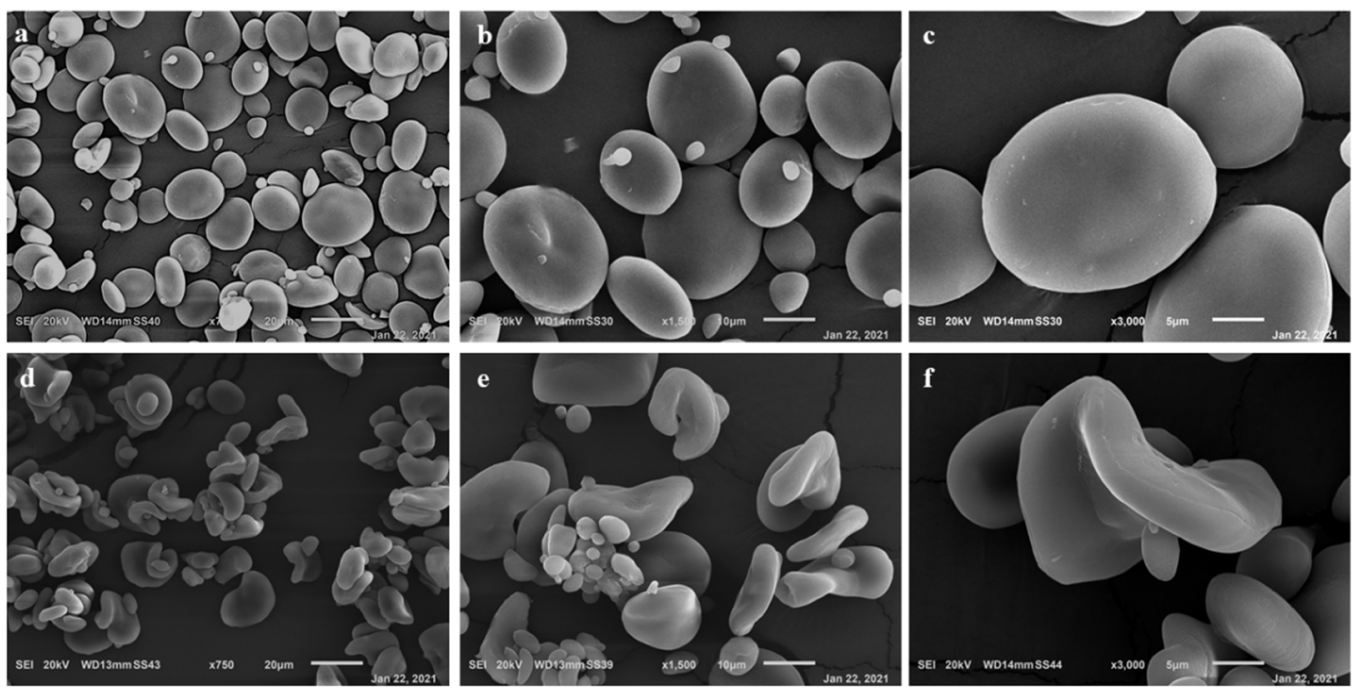

Figure 2. Scanning electron micrographs of isolated starch granules. (a-c) Cadenza (St Starch) and (d-f) Cadenza SBEIIa (HA Starch).

No significant differences were observed for the total starch between Cadenza and Cadenza SBEIIa (Table 1). A different starch composition was determined between the control (Cadenza) and the high amylose genotype (Cadenza SBEIIa) $(p<0.05)$. In particular, the amylose contents were $32 \%$ and $63.1 \%$ of the total starch respectively (Table 1 ). A similar behavior was observed for the resistant starch; this fraction was higher in the high amylose genotype than the control (6.9\% vs $0.8 \%)$.

Table 1. Characterization of starch composition in different bread wheat genotypes. Data are represented as the mean and $\mathrm{SD}$, different letters $(\mathrm{a}, \mathrm{b})$ show significantly different values after one-way ANOVA, followed by Tukey's HSD post hoc test were performed.

\begin{tabular}{cccc}
\hline Genotype & Total Starch (\%) & Resistant Starch (\%) & Amylose (\%) \\
\hline Cadenza & $58.9 \pm 0.1 \mathrm{a}$ & $0.8 \pm 0.2 \mathrm{a}$ & $32.0 \pm 0.5 \mathrm{a}$ \\
Cad-SBEIIa & $57 \pm 0.9 \mathrm{a}$ & $6.9 \pm 0.4 \mathrm{~b}$ & $63.1 \pm 2.9 \mathrm{~b}$ \\
\hline
\end{tabular}

\subsection{Preliminary In Vitro Antibacterial Activity}

Pst growth inhibition was reported as a percentage (Figure 3). Experiment points out a statistically significant difference among these $(p<0.01)$. $\mathrm{CH}$ showed a total inhibition, comparable to copper hydroxide's one, at both $0.5 \%$ and $1 \% \mathrm{w} / \mathrm{v}$ concentrations. MIC was established for chitosan hydrochloride at $0.5 \% \mathrm{w} / \mathrm{v}$ since lower tested concentrations have shown no significant activity on Pst growth. CNC showed no inhibition effects on Pst, and so both types of ST when used at $0.5 \%$ and $1 \% \mathrm{w} / \mathrm{v}$ concentrations. Lower concentrations of ST instead seem to promote Pst growth. This behavior is coherent with the ones showed in previous works, where chitosan, although in different forms, was able to explicate an antibacterial effect on several plant pathogenic bacteria [25,32,33]. Chitosan modes of action against bacteria still remain unclear, even if modern studies have suggested that they could be related to the cationic nature of $\mathrm{NH}_{3}$ groups present in chitosan molecules, which easily interact with negatively charged bacterial cell membrane. This interaction 
could lead to an alteration of membrane permeability, resulting in an inefficient capability of exchange molecules from outer to inner cell environment; Gram-negative bacteria, due to their higher presence of negative charges onto their membranes, appear to be more sensitive to chitosan $[33,73,74]$. Other mechanisms that were proposed to explain chitosan antibacterial activity are associated to the capability of disturbing biofilm formation, which is essential for disease development in some bacteria, and to the behavior of chelating metal ions, subtracting them to bacterial cells [75-78].

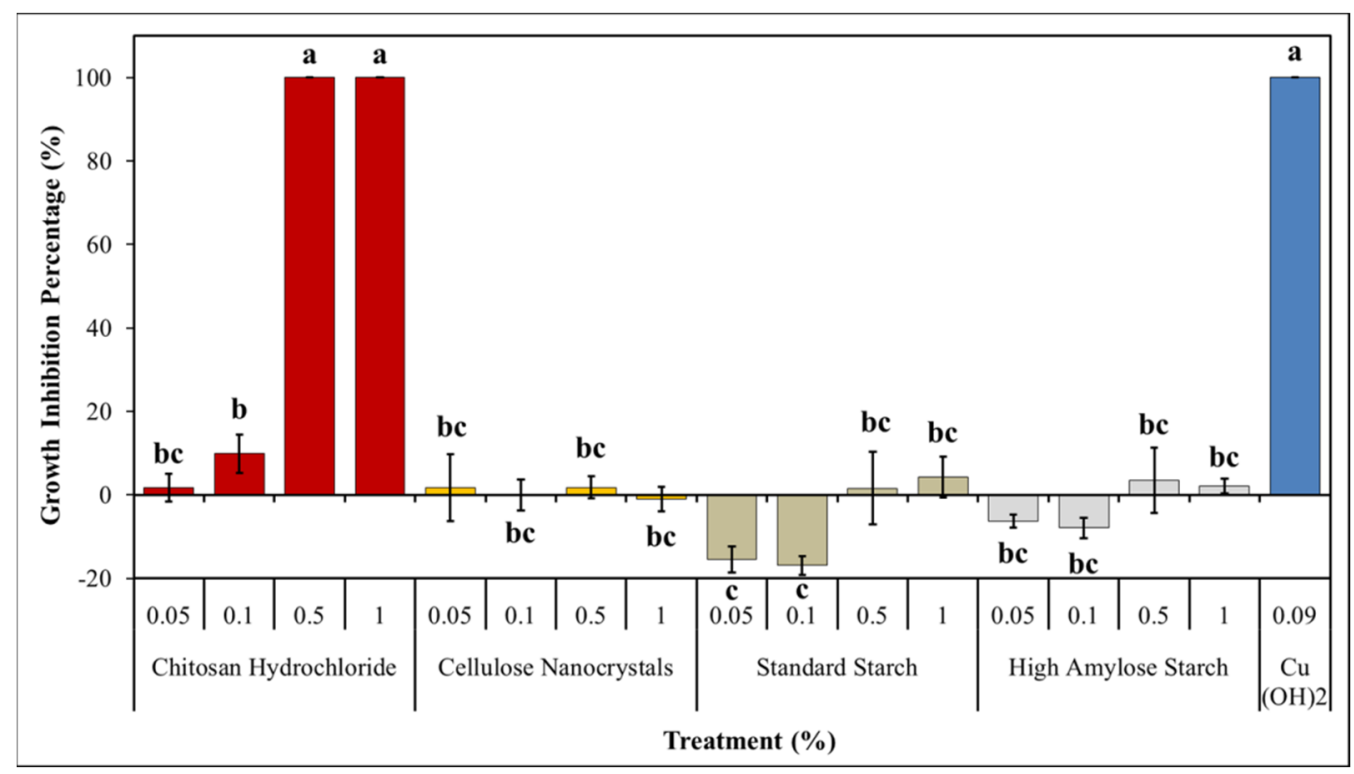

Figure 3. In vitro Pst growth inhibition percentage. MIC was assessed as the concentration on which inhibition on amended KB plates was equal to $100 \%$ after $48 \mathrm{~h}$ of incubation at $27{ }^{\circ} \mathrm{C}$. Data are represented as the mean and SD, different letters $(a, b, c)$ show significantly different values after one-way ANOVA, followed by Tukey's HSD post hoc test were performed.

\subsection{Synthesis and Charachterization of $\mathrm{CH}-\mathrm{CNC}$-Starch NMP}

The obtained NMP showed good $\mathrm{CH}$ content very closed to the theoretical value of $50 \% \mathrm{w} / \mathrm{w}$, as shown in Table 2 . The powders had good homogeneity with \%RSD values of 6.4 and 7.5. No major differences were observed when employing HA Starch or St Starch. A reasonable yield of the process slightly above $50 \%$ was achieved.

Table 2. Chitosan content and yield for the spray-dried NMP preparations containing St Starch or HA Starch. Replicates are displayed to highlighted powder content homogeneity $(n=4, n=3)$.

\begin{tabular}{|c|c|c|c|c|c|c|}
\hline \multicolumn{7}{|c|}{ CH-CNC-HA Starch NMP } \\
\hline \multirow{2}{*}{ Sample } & \multirow{2}{*}{ Powder (g) } & \multirow{2}{*}{ Chitosan (g) } & \multicolumn{2}{|c|}{ CC $(\% \mathrm{w} / \mathrm{w})$} & \multirow{2}{*}{$\%$ RSD } & \multirow{2}{*}{ Yield } \\
\hline & & & Replicates & Mean \pm SD & & \\
\hline A1 & 0.0041 & 0.00176 & 43.0 & \multirow{4}{*}{$45.1 \pm 2.9$} & \multirow{4}{*}{6.4} & \multirow{4}{*}{$52 \%$} \\
\hline $\mathrm{A} 2$ & 0.0042 & 0.00184 & 43.9 & & & \\
\hline A3 & 0.0045 & 0.00222 & 49.3 & & & \\
\hline A4 & 0.0045 & 0.00199 & 44.2 & & & \\
\hline \multicolumn{7}{|c|}{ CH-CNC-St Starch NMP } \\
\hline \multirow{2}{*}{ Sample } & \multirow{2}{*}{ Powder (g) } & \multirow{2}{*}{ Chitosan (g) } & \multicolumn{2}{|c|}{$\mathrm{CC}(\% \mathrm{w} / \mathrm{w})$} & \multirow{2}{*}{$\%$ RSD } & \multirow{2}{*}{ Yield } \\
\hline & & & Replicates & Mean \pm SD & & \\
\hline B1 & 0.0039 & 0.00167 & 42.8 & & & \\
\hline B2 & 0.0041 & 0.00196 & 47.8 & $46.7 \pm 3.5$ & 7.5 & $55 \%$ \\
\hline B3 & 0.0040 & 0.00198 & 49.5 & & & \\
\hline
\end{tabular}


The NMP showed overlapping size distributions with average size ranging around 2.9-3.8 $\mu \mathrm{m}$ (Figure 4). The analysis of particle morphology revealed at least two major dispersed populations: one formed by larger and smoother particles of about $10 \mu \mathrm{m}$ in size and one constituted by smaller and rougher microparticles less than $5 \mu \mathrm{m}$ in size (Figure $4 \mathrm{a}, \mathrm{b}$ ), which a closer observation confirmed to be formed by elongated nanostructures resembling those of CNC or starch material (data not shown). No relevant differences were observed when employing high amylose starch or standard starch.
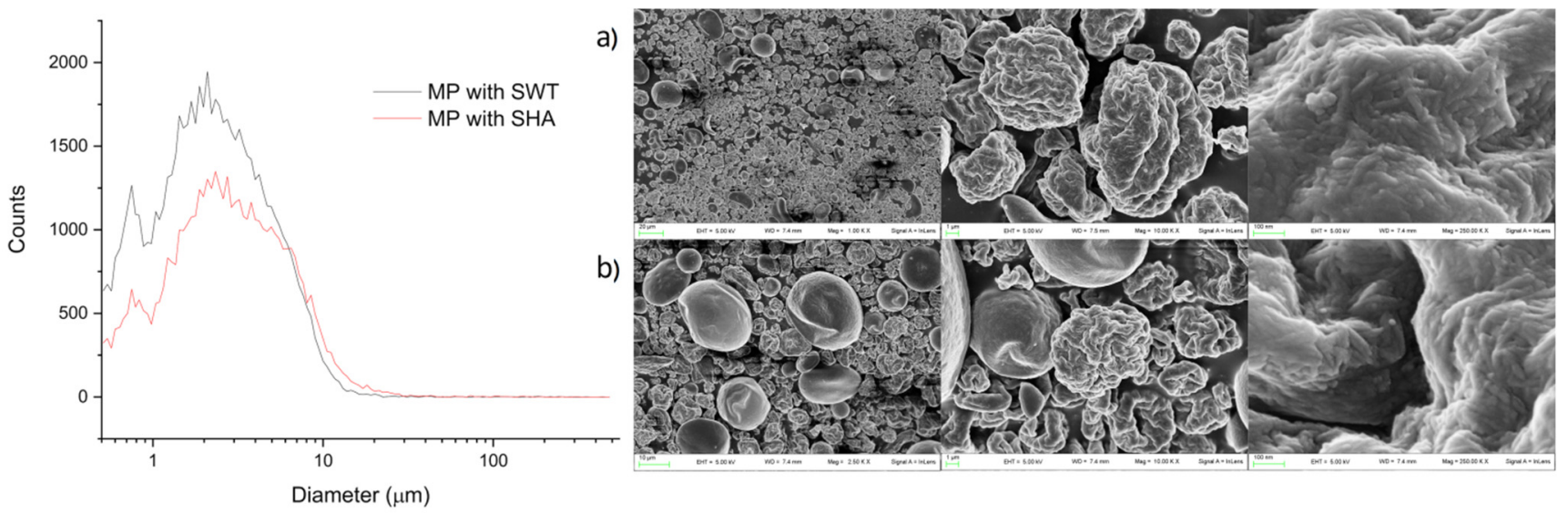

Figure 4. Particle size distributions (left) and SEM microphotographs (right) of the spray-dried NMP containing St Starch (a) or HA Starch (b). Picture were recorded at increasing magnifications. Images were recorded at 2.5, 10.0 and $250 \mathrm{kX}$, respectively.

As already reported above for $\mathrm{CNC}$, the IR spectra of $\mathrm{CH}$, starches and $\mathrm{CNC}$ did not show particular changing in the main signals. For both NMP formulations, chitosan signals prevail over the other components with no significant differences. In particular, the amide bands of chitosan around 1640 and $1500 \mathrm{~cm}^{-1}$ are predominant in the NMP profiles regardless of the starch type employed (Figure 5). This is consistent with the CC values of nearly 50\% for both NMP formulations, as reported in Table 2.

On the other hand, most of the CNC and SHA or SWT signals overlap, with the only exception of a sharper $\mathrm{CNC}$ OH stretching around $3400 \mathrm{~cm}^{-1}$, which perhaps contributes to the corresponding band in the NMP profiles.

Overall, ATR-IR analysis showed that there is no major interaction among the different components, as no band shifts or distortions were observed.

$\mathrm{CH}$ was initially released fast, with up to $40 \%$ of the polymer freed after 1 h (Figure 6a).

The in vitro release profiles plateaued after $24 \mathrm{~h}$, reaching around $50 \%$ for NMP with high amylose starch and 30\% for NMP with standard starch. This behavior may be explained considering the gelling capacity of HA starch, which as observed in other cases [79], may enhance swelling thus promoting particle dispersion/dissolution and $\mathrm{CH}$ release.

However, mass balance analysis showed that the amount of $\mathrm{CH}$ remaining in the pellet at the end of the release period was about $30 \% \mathrm{w} / \mathrm{w}$ for both formulations. As a consequence, the total amount neared $80 \% \mathrm{w} / \mathrm{w}$ in the case of HA Starch and only 50\% w/w for St starch, suggesting significant $\mathrm{CH}$ losses (Figure 6b). This behavior demands further investigation. Hypotheses include potential $\mathrm{CH}$ adhesion to surfaces, precipitation or other interactions with resulting detection issues and material loss. Further studies are also needed in order to investigate effects on release by modifying spray-drying parameters, such as components ratio, feed and aspirator rate, inlet temperature and air pressure. Although spray-drying isn't the best performing technique in terms of regular size of obtained particles, spray-drying allows working with thermally sensitive compounds, such as natural substances. 


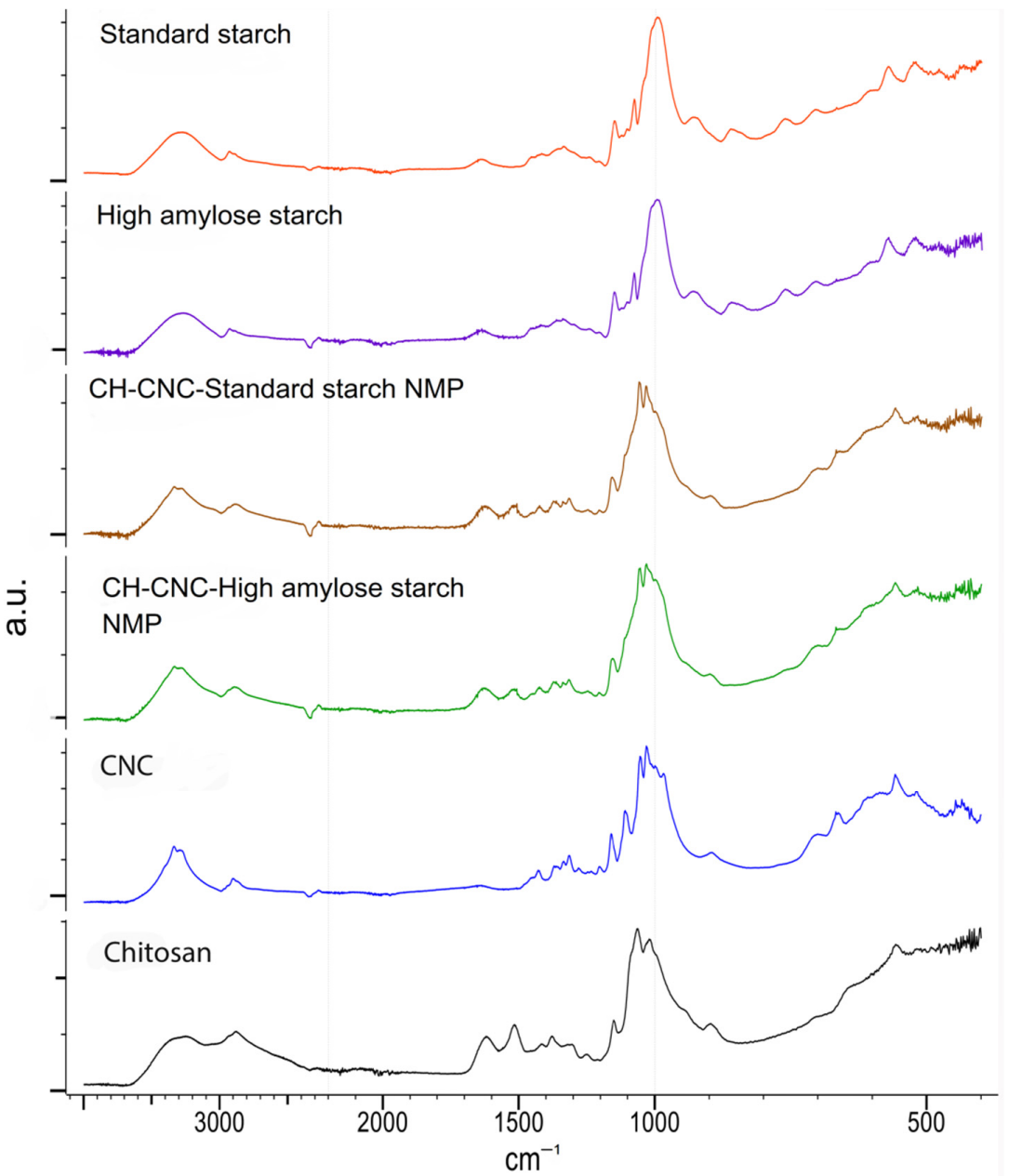

Figure 5. ATR-IR profiles of spray-dried NMP containing St Starch or HA Starch in comparison with the single formulation components. Spectra were acquired on unprocessed powders.

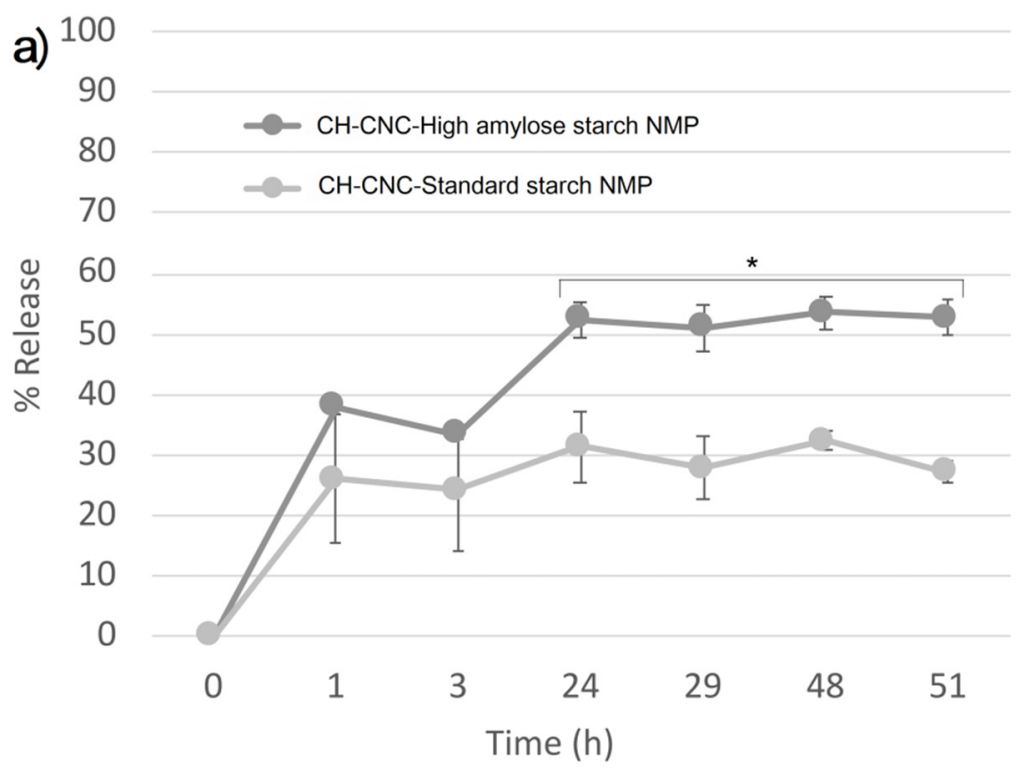

Figure 6. Cont. 


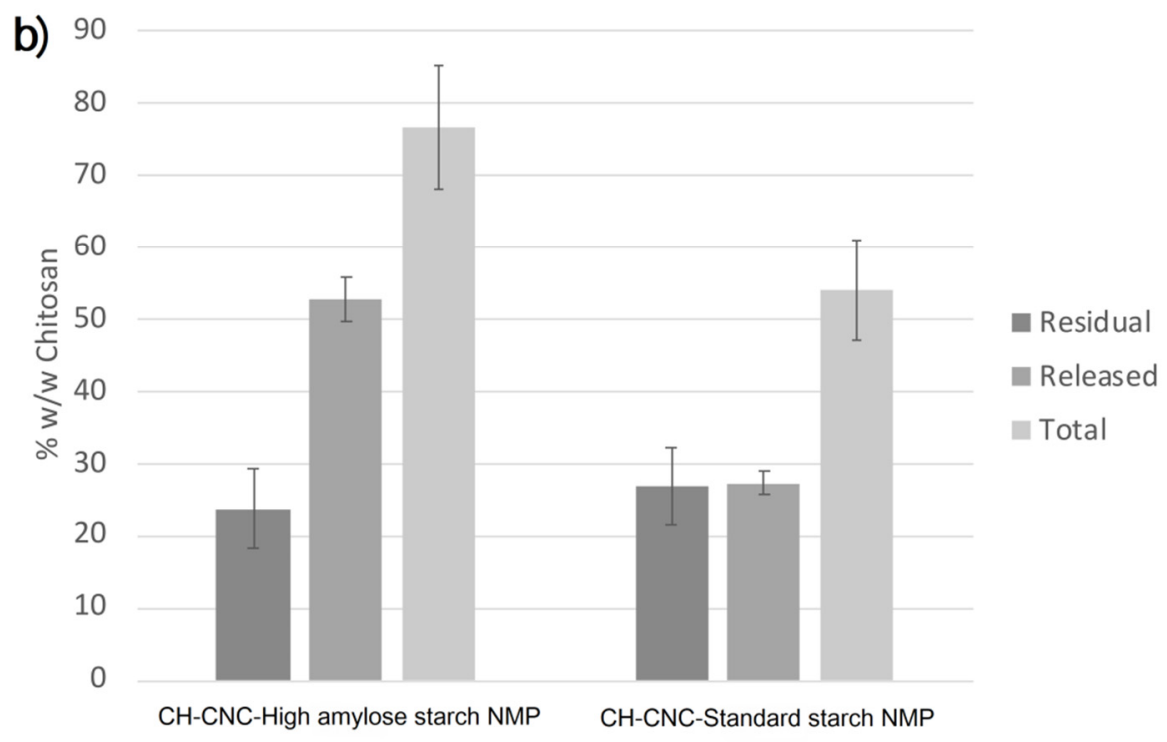

Figure 6. In vitro release profiles of chitosan from spray-dried NMP containing St Starch or HA Starch (a) and mass balance analysis (b) of the residual polymer remaining at the end of the time period investigated. Asterisk indicates significantly different values after one-way ANOVA, followed by Student's $t$-test at 95\% significance level were performed.

In vitro antibacterial activity of both proposed NMP was tested using a microdilution method. Results were expressed as percentage as reported in Figure 7 . At 48 h, a highly significant effect $(p<0.01)$ on Pst growth was recorded for $\mathrm{CH}-\mathrm{CNC}-\mathrm{HA}$ Starch NMP and CH-CNC-St Starch NMP when used at 1\% w/v (Figure 7a). Similarly, to copper hydroxide treatment, a whole bacterial inhibition was reached. Results are consistent with those obtained in preliminary antibacterial assay, where MIC for $\mathrm{CH}$ was recorded at $0.5 \% \mathrm{w} / \mathrm{v}$ after $48 \mathrm{~h}$. Indeed, $\mathrm{CH}$ content in NMP was seen to be equal to $50 \%$. Surprisingly, an interesting inhibitory effect was recorded for both NMP when used at lower concentrations. In particular, growth inhibition values of 80.9 and $75.2 \%$ were noted at $0.5 \% \mathrm{w} / \mathrm{v}$ for $\mathrm{CH}-\mathrm{CNC}-\mathrm{HA}$ Starch NMP and CH-CNC-St Starch NMP, respectively, while when used at $0.1 \% \mathrm{w} / \mathrm{v}$, NMP containing high amylose or standard starch showed values of 36.4 and $31.2 \%$. The differences in antimicrobial activity of $\mathrm{CH}$ with respect to preliminary assay can be explained due the presence of starch, which was able to enhance $\mathrm{CH}$ dispersion. The functionalization of $\mathrm{CH}$ with starch is therefore a prosecutable way to boost antibacterial effectiveness while at the same time reducing the used amount of active principle. At $72 \mathrm{~h}$, a similar behavior was recorded for both NMP with lower inhibition effects on Pst growth (Figure $7 \mathrm{~b}$ ). However, at $1 \% \mathrm{w} / \mathrm{v}$ concentration neither of two NMP was able to fully inhibit the bacterial growth, as their activity could be compared to copper hydroxide's one $(p<0.01)$. Eventually, no bactericidal effect was recorded for tested substances, except for copper hydroxide, since Pst colonies formation was observed in plates after incubating the bacterial suspensions. The decrease in Pst inhibition during time and the absence of recorded values of MBC for tested NMP could find an explanation if $\mathrm{CH}$ antimicrobial effects are considered as bacteriostatic rather than bactericidal [73,78]. Obtained results induced the application of both NMP at $1 \% \mathrm{w} / \mathrm{v}$ in following in vivo experiments, in order to achieve the best antibacterial effect during time. 

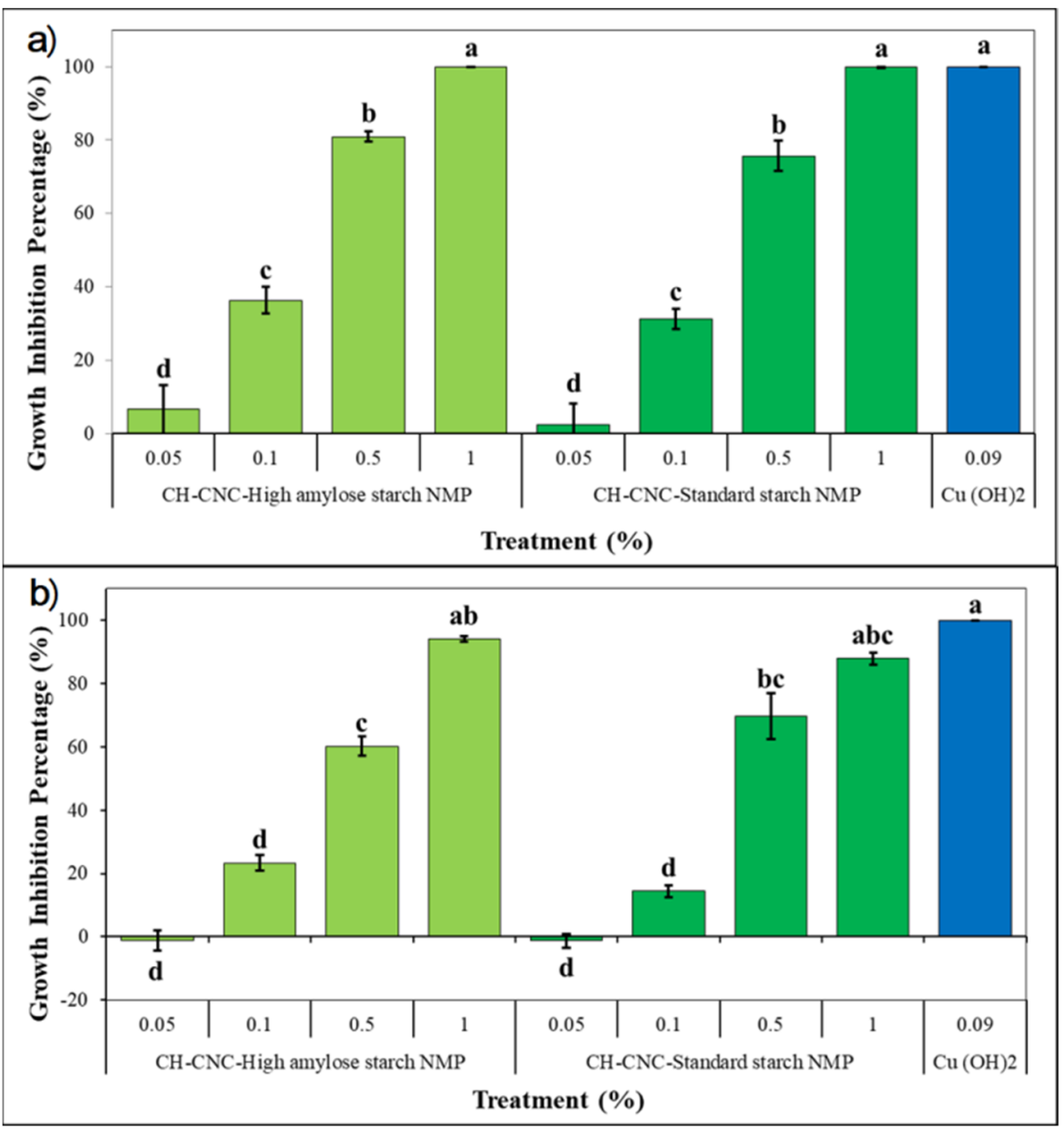

Figure 7. Pst growth inhibition of synthetized NMP was studied through a microdilution method. After $48 \mathrm{~h}(\mathbf{a})$ and $72 \mathrm{~h} \mathrm{(b)}$ of incubation at $27^{\circ} \mathrm{C}$ absorbance at $600 \mathrm{~nm}$ was measured for each sample. MIC was defined as the one in which inhibition was equal to $100 \%$, while MBC was defined as the one in which no colonies formation was observed after plating bacterial suspensions. Data are represented as the mean and SD; different letters (a, b, c, d) show significantly different values after one-way ANOVA, followed by Tukey's HSD post hoc test were performed.

\subsection{CH-CNC-Starch NMP Phytobiological Compatibility}

Biological parameters linked to plant basal physiological functions, such as leaf development and nitrogen use efficiency, were monitored in tomato seedlings in order to study the compatibility of tested NMP with plant growth, as reported in Table 3. At all the time points, no significant differences were recorded among the different theses in terms of developed leaf area. In the same way, no statistical differences were observed in leaf chlorophyll and flavonols content (Table 3). NBI, given by the ratio of these values, indicates the pathway of nitrogen in photosynthetic tissues, assuming that when plant status is healthy, most of its primary metabolism is involved in photosynthetic-related proteins synthesis, like chlorophylls ones, instead of taking part in flavonols pathway, which is associated to plant response to abiotic stresses [72]. Previous studies have demonstrated how CNC can be used without harmful effects on tomato plants, suggesting their potential use as nanocarriers [53]. Furthermore, chitosan effects on plant vegetative growth are positive when applied on leaves $[20,26,31]$. Our work strongly confirms this response, indicating in both formulation of CH-CNC-Starch NMP the capability of evenly covering tomato leaves without any detrimental side effects on basal vegetative parameters (Figure 8). The presence of a whitish spotty patina was noticed on leaves of plants treated with both NMP (Figure 8a)-its making should be due to the natural polymerization tendency of $\mathrm{CNC}$ and 
starch. Despite this, no phytotoxic effects were recorded on tomato seedlings during the trial, assessing the full compatible use of NMP on living tomato plants.

Table 3. Tomato seedlings' biological parameters measurements for each treatment at different times. Three leaves per plant were collected to assess mean area using a scanning software. Three measurements on the second leaf of each plant were performed using a leaf clip sensor to assess chlorophyll and flavonols content, whose ratio was used to calculate nitrogen balance index. Means and SD are reported after one-way ANOVA was performed.

\begin{tabular}{ccccc}
\hline Treatment & Biological Parameters & \multicolumn{3}{c}{ Days Post Treatment } \\
\hline & & $\mathbf{1 ~ d p t}$ & $\mathbf{7 ~ d p t}$ & $\mathbf{1 4} \mathbf{~ d p t}$ \\
\hline \multirow{2}{*}{ Water } & Leaf Area $\left(\mathrm{cm}^{2}\right)$ & $3.8 \pm 0.1$ & $4.0 \pm 0.2$ & $7.1 \pm 0.7$ \\
& Chlorophyll Content (DU) & $27.6 \pm 1.0$ & $26.9 \pm 1.9$ & $28.0 \pm 0.6$ \\
& Flavonols Content (DU) & $0.56 \pm 0.04$ & $0.39 \pm 0.01$ & $0.41 \pm 0.02$ \\
& Nitrogen Balance Index & $59.3 \pm 3.5$ & $71.2 \pm 5.1$ & $71.4 \pm 2.5$ \\
\hline \multirow{2}{*}{ Copper } & Leaf Area (cm ${ }^{2}$ ) & $3.4 \pm 0.1$ & $5.6 \pm 0.5$ & $7.8 \pm 1.2$ \\
Hydroxide & Chlorophyll Content (DU) & $27.8 \pm 1.3$ & $29.4 \pm 1.0$ & $28.2 \pm 0.8$ \\
& Flavonols Content (DU) & $0.74 \pm 0.06$ & $0.44 \pm 0.03$ & $0.38 \pm 0.01$ \\
& Nitrogen Balance Index & $45.1 \pm 4.4$ & $71.2 \pm 3.4$ & $75.6 \pm 2.3$ \\
\hline \multirow{2}{*}{ CH-CNC- } & Leaf Area (cm ${ }^{2}$ ) & $3.7 \pm 0.2$ & $5.0 \pm 0.6$ & $7.3 \pm 0.8$ \\
Standard starch & Chlorophyll Content (DU) & $26.2 \pm 1.1$ & $26.1 \pm 0.6$ & $28.6 \pm 1.0$ \\
NMP & Flavonols Content (DU) & $0.58 \pm 0.04$ & $0.45 \pm 0.03$ & $0.38 \pm 0.01$ \\
& Nitrogen Balance Index & $50.9 \pm 3.6$ & $63.0 \pm 2.9$ & $75.8 \pm 2.8$ \\
\hline \multirow{2}{*}{ CH -CNC-High } & Lhlorophyll Content (DU) & $27.6 \pm 0.9$ & $28.1 \pm 1.6$ & $28.7 \pm 0.5$ \\
amylose NMP & Flavonols Content (DU) & $0.69 \pm 0.06$ & $0.42 \pm 0.03$ & $0.46 \pm 0.03$ \\
& Nitrogen Balance Index & $46.2 \pm 3.0$ & $69.4 \pm 2.9$ & $67.1 \pm 3.4$ \\
\hline
\end{tabular}

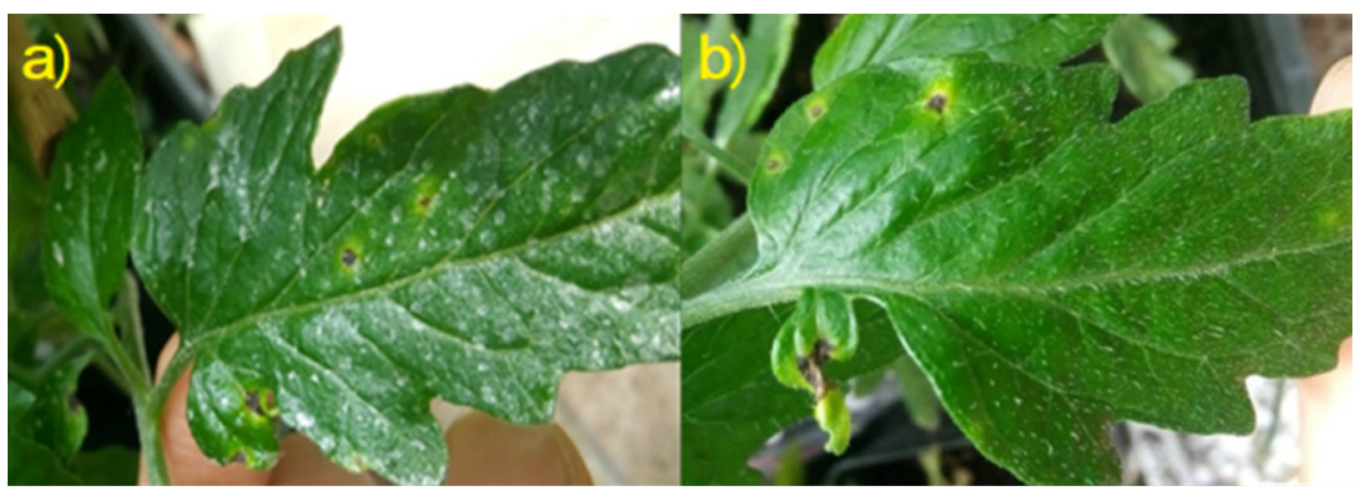

Figure 8. Particular tomato leaves treated with CH-CNC-HA Starch NMP (a) and with Water (b). Point-like necrosis surrounded by a chlorotic halo, which are the typical tomato speck symptoms, as well as the whitish patina that evenly covers the leaf when treated with NMP.

\subsection{In Vivo Antibacterial Activity}

Antibacterial effect of proposed NMP was assessed in vivo studying Pst epiphytic survival and symptomatic expression on artificially inoculated tomato leaves. At $1 \mathrm{dpi}$, $\mathrm{CH}-\mathrm{CNC}$-HA Starch NMP treatment showed a significant $(p<0.05)$ reduction in terms of bacterial epiphytic survival, with $1.37 \times 10^{1} \mathrm{CFU} \mathrm{\textrm {cm } ^ { - 2 }}$. At $7 \mathrm{dpi}$, both tested NMP in a comparable way to the copper hydroxide, showed an highly significant $(p<0.01)$ effect on Pst epiphytic survival. $\mathrm{N}^{\circ}$ of $\mathrm{CFU} \mathrm{cm}^{-2}$ in plants treated with copper was equal to $1.20 \times 10^{3}$, while for CH-CNC-HA Starch NMP and CH -CNC-St Starch NMP was $2.58 \times 10^{3}$ and $2.88 \times 10^{3}$, respectively. At $14 \mathrm{dpi}$, NMP with high amylose starch and copper hydroxide showed both a highly significant $(p<0.01)$ reduction of bacterial epiphytic survival recording values of $9.59 \times 10^{3}$ and $5.84 \times 10^{3} \mathrm{CFU} \mathrm{cm}^{-2}$ (Figure 9). 


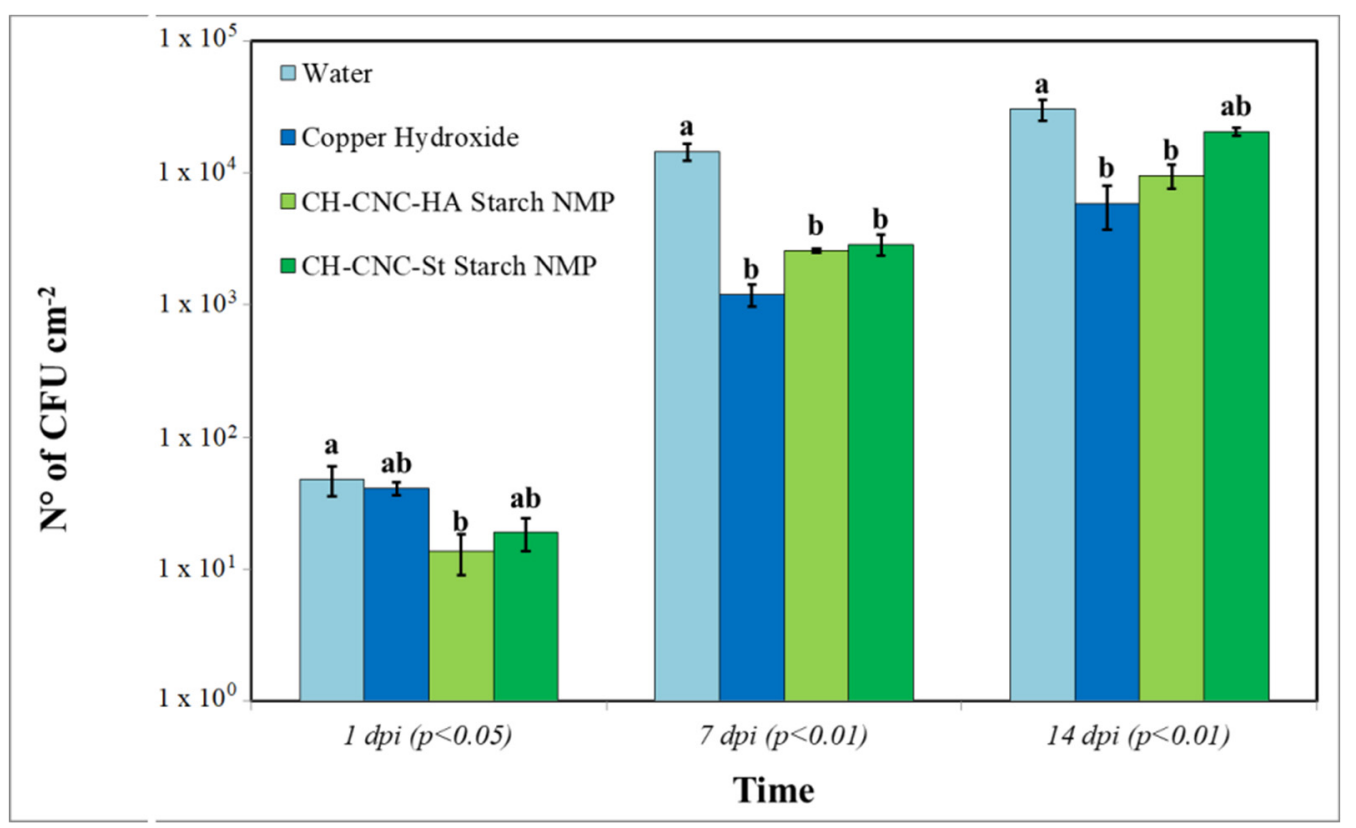

Figure 9. Pst epiphytical survival on tomato leaves at different time points. Three leaves per plant were collected, washed and measured in order to relate developed bacterial colonies to the leaf area. Data are represented as the mean and SD; different letters $(a, b)$ show significantly different values after one-way ANOVA, followed by Tukey's HSD post hoc test were performed.

Symptoms monitoring on leaves during the trials has produced the following results: symptoms (chlorotic spots and necrosis) started to appear since the fifth day after inoculation. At $7 \mathrm{dpi}$, all plants belonging to different theses showed symptoms. DS calculated at 7 dpi showed a highly significant difference $(p<0.01)$ in developed point-like necrosis on tomato seedlings treated with both NMP with respect to the untreated sample; in particular, CH-CNC-HA Starch NMP has registered a mean value of 20.6 necrosis per plant, while CH-CNC- St Starch NMP has registered a mean value of 19.1 necrosis per plant. Necrosis count on plants treated with copper showed a reduction of 34.1\%, while for NMP with high amylose starch and for NMP with standard starch values of $49.9 \%$ and $45.9 \%$ were reached (Table 4); nonetheless, these differences were not statistically significant, assuming that both NMP treatments could be compared to copper hydroxide one in terms of disease reduction.

Table 4. Disease severity (DS) is expressed as the number of point-like necrosis per plant at 7 dpi. Disease symptoms reduction (DR) was calculated as percentage ratio between plant disease severity, using water as a control. Data are represented as the mean and SD; different letters $(a, b)$ show significantly different values after one-way ANOVA, followed by Tukey's HSD post hoc test were performed.

\begin{tabular}{ccc}
\hline \multirow{2}{*}{ Treatment } & \multicolumn{2}{c}{ 7 Days Post Inoculation $(p<\mathbf{0 . 0 1 )}$} \\
\cline { 2 - 3 } & DS (Necrosis Per Plant) & DR (\%) \\
\hline Water & $38.1 \pm 4.9 \mathrm{a}$ & - \\
Copper Hydroxide & $25.1 \pm 2.9 \mathrm{ab}$ & $34.1 \pm 7.9$ \\
CH-CNC-HA Starch NMP & $20.6 \pm 2.8 \mathrm{~b}$ & $49.9 \pm 7.5$ \\
CH-CNC-St Starch NMP & $19.1 \pm 3.7 \mathrm{~b}$ & $45.9 \pm 9.6$ \\
\hline
\end{tabular}

Disease incidence of bacterial speck was assessed at 7 and $14 \mathrm{dpi}$. In both cases, either NMP were able to drastically reduce the incidence of the disease, in a comparable way to copper hydroxide, used as positive control $(p<0.01)$. At $7 \mathrm{dpi}$, theses treated with both NMP showed a disease incidence of 3\%, while copper hydroxide at field dose $2.3 \%$. Similar trend was recorded at $14 \mathrm{dpi}$, with value of disease incidence equal to 3, 2.7 and 3.5\% for 
theses treated with CNC-SHA-CH NMP-HA Starch, CH-CNC-St Starch NMP and copper hydroxide, respectively (Table 5).

Table 5. Disease incidence (DI) of theses calculated as percentage ratio between total necrotized area and total area of collected leaves for the assessing of Pst epiphytical survival. Data are represented as the mean and SD, different letters $(a, b)$ show significantly different values after one-way ANOVA, followed by Tukey's HSD post hoc test were performed.

\begin{tabular}{|c|c|c|}
\hline \multirow{2}{*}{ Treatment } & \multicolumn{2}{|c|}{ Disease Incidence $(\%)(p<0.01)$} \\
\hline & $7 \mathrm{dpi}$ & $14 \mathrm{dpi}$ \\
\hline Water & $4.8 \pm 0.2 \mathrm{a}$ & $4.9 \pm 0.3 \mathrm{a}$ \\
\hline Copper Hydroxide & $2.3 \pm 0.2 b$ & $3.5 \pm 0.4 \mathrm{~b}$ \\
\hline CH-CNC-HA Starch NMP & $3 \pm 0.4 \mathrm{~b}$ & $3 \pm 0.2 b$ \\
\hline CH-CNC-St Starch NMP & $3 \pm 0.2 b$ & $2.7 \pm 0.04 b$ \\
\hline
\end{tabular}

In vivo results point out the possibility of using proposed NMP as sustainable substitutes of copper hydroxide, due to the comparable obtained effects in terms of reduction of Pst epiphytical survival and symptomatic expression. These results can be explained considering the afore mentioned antimicrobial properties of chitosan. Moreover, the effects of the NMP different formulation have to be considered. The presence of starch in both tested NMP could have promoted $\mathrm{CH}$ release and its consequent antibacterial effects on Pst epiphytical bacterial population. The rapid and statistically confirmed effect on reducing bacterial epiphytic survival of NMP with high amylose starch after the inoculation could be due to the presence of the high amylose starch, which already recorded a greater $\mathrm{CH}$ release in the in vitro assays. The presence of more water-soluble polymers in high amylose starch could explain the speed in making available the active principle. Many studies showed high amylose starch has improved properties of controlled drug delivery in relation to conventional starch [80].

A better readiness of the compound involves a higher bacterial inhibition on the inoculated Pst population, so as to allow a reduction in subsequent levels of epiphytic bacterial populations. In support of this, although a similar behavior was shown in plants treated with NMP with standard starch, a general higher $\mathrm{n}^{\circ}$ of $\mathrm{CFU} \mathrm{\textrm {cm } ^ { - 2 }}$ was recorded. Symptoms expression on leaves is related to levels of bacterial population - indeed, where lower CFU $\mathrm{cm}^{-2}$ are recorded, an improvement of disease indices can be observed, in terms of severity, incidence and proportional symptoms reduction [81,82]. Furthermore, in elucidating effectiveness of proposed NMP, another crucial aspect could be involved, which is related to the chitosan property as a plant resistance elicitor. Several resistance induction mechanisms are attributed to chitosan, such as phytoalexins synthesis and plant pathogenesis-related proteins production stimulation [83]. Chitosan is also involved in the systemic acquired resistance of plants, through the induction of genes related to jasmonic acid pathways and protease inhibitors [84]. It has been stated that chitosan plays an important role in plant elicitation mechanisms, acting through cell membrane depolarization as an elicitor in the early phases of these processes [85]. Resistance elicitor properties mainly depend on chitosan molecular weight, the degree of polymerization and acetylation and oligomers compositions [20]. Foliar application of high-density chitosan in tomato plants affected by bacterial spot revealed an increase of peroxidases, which are associated to lignin deposition and the production of toxic metabolites for pathogens [32]. Further experiments are unfolding in order to study expression of genes related to resistance mechanisms in tomatoes when both seeds and adult plants are treated with chitosan, especially in alternative nanometric forms. Additionally, $\mathrm{CNC}$ and starch could also have had a role in diminishing bacterial infections, creating an unsuitable environment for Pst acting as physical barriers around penetrations sites [53]. There is a high probability that in vivo antimicrobial properties of tested NMP could derive from the interaction of all cited effects. 


\section{Conclusions}

The present study describes the effects of an innovative green organic nanostructured compound to counteract tomato bacterial speck disease. Obtained results showed how chitosan hydrochloride, a more water-soluble form of chitosan, possesses a full inhibitory activity on Pseudomonas syringae pv. tomato at low concentrations $(0.5 \% \mathrm{w} / \mathrm{v})$. In order to facilitate chitosan hydrochloride dispersion on plant canopy and to control its release during time, a nanostructured pesticide was synthetized by the spray-drying technique. Cellulose nanocrystals, due to their chemical properties-among which was the already documented biocompatibility-were proposed as nanocarriers. At the same time, two different types of starch, extracted from a standard and a high amylose content bread wheat cultivars, were investigated to assess their effects on chitosan hydrochloride release. Results confirm the possibility of using the Cadenza SBEIIa genotype as source of high amylose content starch. Obtained nanostructured microparticles were characterized for their biochemical properties, revealing a mean size of 2.9-3.8 $\mu \mathrm{m}$, and an achieved loading of $50 \% \mathrm{w} / \mathrm{w}$ in terms of chitosan hydrochloride content. In vitro chitosan release assay has, as expected, shown a higher release for microparticles embedded with high amylose starch, capable of releasing half of loaded chitosan after $24 \mathrm{~h}$, while microparticles with standard starch reached the $30 \%$. Both of microparticles when used at $1 \% \mathrm{w} / \mathrm{v}$ were able to fully inhibit bacterial growth after $48 \mathrm{~h}$, showing a bacteriostatic effect that persists at $72 \mathrm{~h}$, with a slightly decrease for microparticles with standard starch. In vivo experiments assessed the complete biocompatibility of proposed nanostructured pesticides when foliar is applied at $1 \% \mathrm{w} / \mathrm{v}$, demonstrating no harmful effects on the vegetative development of tomato plants. At the same time, both microparticles were able to diminish the epiphytical bacterial survival and the disease incidence at seven and fourteen days after artificial Pst inoculation. At seven days after inoculation, a significant drop in disease severity with a proportional symptoms reduction was observed, ranging from $45 \%$ to $49 \%$, comparable to the one showed by copper hydroxide. This study highlights the concrete possibility of using an organic nanostructured pesticide in replacement of copper, opening new scenarios in sustainable tomato crop protection strategies against bacterial diseases. Further studies have been programmed in order to better clarify chitosan hydrochloride effects on tomato resistance induction, and to investigate nanostructured microparticles behavior in field, as well as to study, through the application of fluorescent markers, uptake and translocation of proposed nanopesticides in living plant tissues.

Author Contributions: Conceptualization, D.S., G.M.B. and S.G.; methodology, G.M.B., S.G., E.C. and F.S.; validation, G.M.B. and S.G.; investigation, D.S., E.B. and R.B.; resources, G.M.B. and F.S.; data curation, D.S., R.B. and E.B.; writing—original draft preparation, D.S., F.S. and S.G.; writing-review and editing, G.M.B., E.C. and S.G.; supervision, G.M.B., E.C. and F.S.; and project administration, G.M.B. All authors have read and agreed to the published version of the manuscript.

Funding: This research was funded by MUR (Italian Ministry for University and Research) (Law 232/2016, Departments of Excellence) and by POR FESR Lazio Region (2014-2020) (GRAEEN project, Strategic Projects-Area of Specialization Green Economy DD G04052 4 April 2019, CUP: F14D20000010003.

Conflicts of Interest: The authors declare no conflict of interest.

\section{References}

1. Medina-Pérez, G.; Fernández-Luqueño, F.; Campos-Montiel, R.G.; Sánchez-López, K.B.; Afanador-Barajas, L.N.; Prince, L. Nanotechnology in Crop Protection: Status and Future Trends; Elsevier Inc.: Amsterdam, The Netherlands, 2019; Volume 2018, ISBN 9780128158296.

2. Nuruzzaman, M.; Rahman, M.M.; Liu, Y.; Naidu, R. Nanoencapsulation, Nano-guard for Pesticides: A New Window for Safe Application. J. Agric. Food Chem. 2016, 64, 1447-1483. [CrossRef] [PubMed]

3. Prasad, R.; Bhattacharyya, A.; Nguyen, Q.D. Nanotechnology in sustainable agriculture: Recent developments, challenges, and perspectives. Front. Microbiol. 2017, 8, 1-13. [CrossRef]

4. Preston, G.M. Pseudomonas syringae pv. tomato: The right pathogen, of the right plant, at the right time. Mol. Plant Pathol. 2000, 1, 263-275. [CrossRef] 
5. Babelegoto, N.; Varvaro, L.; Cirulli, M. Epiphytic, and endophytic multiplication of Pseudomonas syringae pv. tomato (Okabel) Young et al. in susceptible and resistant tomato leaves. Phytopathol. Mediterr. 1988, 27, 138-144.

6. McCarter, S.M. Survival of Pseudomonas syringae pv. tomato in Association with Tomato Seed, Soil, Host Tissue, and Epiphytic Weed Hosts in Georgia. Phytopathology 1983, 73, 1393. [CrossRef]

7. Griffin, K.; Gambley, C.; Brown, P.; Li, Y. Copper-tolerance in Pseudomonas syringae pv. tomato and Xanthomonas spp. and the control of diseases associated with these pathogens in tomato and pepper. A systematic literature review. Crop Prot. 2017, 96. [CrossRef]

8. Abrahamian, P.; Jones, J.B.; Vallad, G.E. Efficacy of copper and copper alternatives for management of bacterial spot on tomato under transplant and field production. Crop Prot. 2019, 126. [CrossRef]

9. Obradovic, A.; Jones, J.B.; Momol, M.T.; Balogh, B.; Olson, S.M. Management of tomato bacterial spot in the field by foliar applications of bacteriophages and SAR inducers. Plant Dis. 2004, 88, 736-740. [CrossRef] [PubMed]

10. La Torre, A.; Iovino, V.; Caradonia, F. Copper in plant protection: Current situation and prospects. Phytopathol. Mediterr. 2018, 57, 201-236. [CrossRef]

11. Lamichhane, J.R.; Osdaghi, E.; Behlau, F.; Köhl, J.; Jones, J.B.; Aubertot, J.N. Thirteen decades of antimicrobial copper compounds applied in agriculture. A review. Agron. Sustain. Dev. 2018, 38, 1-18. [CrossRef]

12. Flemming, C.A.; Trevors, J.T. Copper toxicity and chemistry in the environment: A review. Water Air Soil Pollut. 1989, 44, 143-158. [CrossRef]

13. Keller, A.A.; Adeleye, A.S.; Conway, J.R.; Garner, K.L.; Zhao, L.; Cherr, G.N.; Hong, J.; Gardea-Torresdey, J.L.; Godwin, H.A.; Hanna, S.; et al. Comparative environmental fate and toxicity of copper nanomaterials. Nano Impact 2017, 7. [CrossRef]

14. Bender, C.L.; Cooksey, D.A. Indigenous plasmids in Pseudomonas syringae pv. tomato: Conjugative transfer and role in copper resistance. J. Bacteriol. 1986, 165, 534-541. [CrossRef] [PubMed]

15. McLeod, A.; Masimba, T.; Jensen, T.; Serfontein, K.; Coertze, S. Evaluating spray programs for managing copper resistant Pseudomonas syringae pv. tomato populations on tomato in the Limpopo region of South Africa. Crop Prot. 2017, $102,32-42$. [CrossRef]

16. Quattrucci, A.; Ovidi, E.; Tiezzi, A.; Vinciguerra, V.; Balestra, G.M. Biological control of tomato bacterial speck using Punica granatum fruit peel extract. Crop Prot. 2013. [CrossRef]

17. Vargas, P.; Farias, G.A.; Nogales, J.; Prada, H.; Carvajal, V.; Barón, M.; Rivilla, R.; Martín, M.; Olmedilla, A.; Gallegos, M.T. Plant flavonoids target Pseudomonas syringae pv. tomato DC3000 flagella and type III secretion system. Environ. Microbiol. Rep. 2013, 5, 841-850. [CrossRef] [PubMed]

18. Chacón-Hernández, J.; Arredondo-Valdés, R.; Reyes-Zepeda, F.; Hernández-Castillo, F.D.; Anguiano-Cabello, J.C.; Heinz-Castro, R.T.Q.; Mora-Ravelo, S.G. In vitro antibacterial activity of Magnolia tamaulipana against tomato phytopathogenic bacteria. Plant Prot. Sci. 2020, 56, 1-7. [CrossRef]

19. Sabir, A.; El-Khalfi, B.; Errachidi, F.; Chemsi, I.; Serrano, A.; Soukri, A. Evaluation of the Potential of Some Essential Oils in Biological Control against Phytopathogenic Agent Pseudomonas syringae pv. Tomato DC3000 Responsible for the Tomatoes Speck. J. Plant Pathol. Microbiol. 2017, 8. [CrossRef]

20. Li, K.; Xing, R.; Liu, S.; Li, P. Chitin and Chitosan Fragments Responsible for Plant Elicitor and Growth Stimulator. J. Agric. Food Chem. 2020. [CrossRef] [PubMed]

21. De Bona, G.S.; Vincenzi, S.; De Marchi, F.; Angelini, E.; Bertazzon, N. Chitosan induces delayed grapevine defense mechanisms and protects grapevine against Botrytis cinerea. J. Plant Dis. Prot. 2021, 128, 715-724. [CrossRef]

22. Al-Tawaha, A.R.M.; Al-Ghzawi, A.L.A. Effect of chitosan coating on seed germination and salt tolerance of Lentil (Lens culinaris L.). Res. Crop 2013, 14, 489-491.

23. Ziani, K.; Ursúa, B.; Maté, J.I. Application of bioactive coatings based on chitosan for artichoke seed protection. Crop Prot. 2010, 29, 853-859. [CrossRef]

24. Betchem, G.; Johnson, N.A.N.; Wang, Y. The application of chitosan in the control of post-harvest diseases: A review. J. Plant Dis. Prot. 2019, 126, 495-507. [CrossRef]

25. Scortichini, M. Field efficacy of chitosan to control Pseudomonas syringae pv. actinidiae, the causal agent of kiwifruit bacterial canker. Eur. J. Plant Pathol. 2014, 140, 887-892. [CrossRef]

26. Pichyangkura, R.; Chadchawan, S. Biostimulant activity of chitosan in horticulture. Sci. Hortic. Amst. 2015, 196, 49-65. [CrossRef]

27. Hemantaranjan, A. A Future Perspective in Crop Protection: Chitosan and its Oligosaccharides. Adv. Plants Agric. Res. 2014, 1, 1-8. [CrossRef]

28. Hassan, O.; Chang, T. Chitosan for Eco-friendly Control of Plant Disease. Asian J. Plant Pathol. 2017, 11, 53-70. [CrossRef]

29. Borines, L.; Sagarino, R.; Calamba, R.; Contioso, M.A.; Jansalin, J.G.; Calibo, C. Potential of Chitosan for the Control of Tomato Bacterial Wilt Caused by Ralstonia solanacearum (Smith) Yabuuchi et al. Ann. Trop. Res. 2015, 57-69. [CrossRef]

30. Benhamou, N.; Kloepper, J.W.; Tuzun, S. Induction of resistance against Fusarium wilt of tomato by combination of chitosan with an endophytic bacterial strain: Ultrastructure and cytochemistry of the host response. Planta 1998, 204, 153-168. [CrossRef]

31. El Amerany, F.; Meddich, A.; Wahbi, S.; Porzel, A.; Taourirte, M.; Rhazi, M.; Hause, B. Foliar application of chitosan increases tomato growth and influences mycorrhization and expression of endochitinase-encoding genes. Int. J. Mol. Sci. 2020, 21, 535. [CrossRef] [PubMed] 
32. De Jail, N.G.; Luiz, C.; Da Rocha Neto, A.C.; Di Piero, R.M. High-density chitosan reduces the severity of bacterial spot and activates the defense mechanisms of tomato plants. Trop. Plant Pathol. 2014, 39, 434-441. [CrossRef]

33. Mansilla, A.Y.; Albertengo, L.; Rodríguez, M.S.; Debbaudt, A.; Zúñiga, A.; Casalongué, C.A. Evidence on antimicrobial properties and mode of action of a chitosan obtained from crustacean exoskeletons on Pseudomonas syringae pv. tomato DC3000. Appl. Microbiol. Biotechnol. 2013, 97, 6957-6966. [CrossRef]

34. Signini, R.; Campana Filho, S.P. On the preparation and characterization of chitosan hydrochloride. Polym. Bull. 1999, 42, 159-166. [CrossRef]

35. Francesconi, S.; Steiner, B.; Buerstmayr, H.; Lemmens, M.; Sulyok, M.; Balestra, G.M. Chitosan hydrochloride decreases fusarium graminearum growth and virulence and boosts growth, development and systemic acquired resistance in two durum wheat genotypes. Molecules 2020, 25, 4752. [CrossRef]

36. Fortunati, E.; Giovanale, G.; Luzi, F.; Mazzaglia, A.; Kenny, J.M.; Torre, L.; Balestra, G.M. Effective postharvest preservation of kiwifruit and romaine lettuce with a chitosan hydrochloride coating. Coatings 2017, 7, 196. [CrossRef]

37. Kumar, S.; Nehra, M.; Dilbaghi, N.; Marrazza, G.; Aly, A.; Kim, K. Nano-based smart pesticide formulations: Emerging opportunities for agriculture. J. Control. Release 2019, 294, 131-153. [CrossRef]

38. Alejandro, P.D.L.; Rubiales, D. Nanotechnology for parasitic plant control. Pest Manag. Sci. 2009, 65, 540-545. [CrossRef]

39. Elsharkawy, M.; Derbalah, A.; Hamza, A.; El-Shaer, A. Zinc oxide nanostructures as a control strategy of bacterial speck of tomato caused by Pseudomonas syringae in Egypt. Environ. Sci. Pollut. Res. 2020, 27, 19049-19057. [CrossRef] [PubMed]

40. Li, Y.; Yang, D.; Cui, J. Graphene oxide loaded with copper oxide nanoparticles as an antibacterial agent against: Pseudomonas syringae pv. tomato. RSC Adv. 2017, 7, 38853-38860. [CrossRef]

41. Ocsoy, I.; Paret, M.L.; Ocsoy, M.A.; Kunwar, S.; Chen, T.; You, M.; Tan, W. Nanotechnology in plant disease management: DNA-directed silver nanoparticles on graphene oxide as an antibacterial against Xanthomonas perforans. ACS Nano 2013, 7, 8972-8980. [CrossRef] [PubMed]

42. El-Shetehy, M.; Moradi, A.; Maceroni, M.; Reinhardt, D.; Petri-Fink, A.; Rothen-Rutishauser, B.; Mauch, F.; Schwab, F. Silica nanoparticles enhance disease resistance in Arabidopsis plants. Nat. Nanotechnol. 2021, 16, 344-353. [CrossRef] [PubMed]

43. Ozcan, A.; Young, M.; Lee, B.; Liao, Y.Y.; Da Silva, S.; Godden, D.; Colee, J.; Huang, Z.; Mendis, H.C.; Campos, M.G.N.; et al. Copper-fixed quat: A hybrid nanoparticle for application as a locally systemic pesticide (LSP) to manage bacterial spot disease of tomato. Nanoscale Adv. 2021, 3, 1473-1483. [CrossRef]

44. Fortunati, E.; Verma, D.; Luzi, F.; Mazzaglia, A.; Torre, L.; Balestra, G.M. Novel nanoscaled materials from lignocellulosic sources: Potential applications in the agricultural sector. Handb. Ecomater. 2019, 4, 2657-2679. [CrossRef]

45. Fortunati, E.; Mazzaglia, A.; Balestra, G.M. Sustainable control strategies for plant protection and food packaging sectors by natural substances and novel nanotechnological approaches. J. Sci. Food Agric. 2019, 99, 986-1000. [CrossRef]

46. Campos, E.V.R.; de Oliveira, J.L.; Fraceto, L.F.; Singh, B. Polysaccharides as safer release systems for agrochemicals. Agron. Sustain. Dev. 2015, 35, 47-66. [CrossRef]

47. George, J.; Sabapathi, S.N. Cellulose nanocrystals: Synthesis, functional properties, and applications. Nanotechnol. Sci. Appl. 2015, 8, 45-54. [CrossRef]

48. Roman, M. Toxicity of cellulose nanocrystals: A review. Ind. Biotechnol. 2015, 11, 25-33. [CrossRef]

49. Salas, C.; Nypelö, T.; Rodriguez-Abreu, C.; Carrillo, C.; Rojas, O.J. Nanocellulose properties and applications in colloids and interfaces. Curr. Opin. Colloid Interface Sci. 2014, 19, 383-396. [CrossRef]

50. Kamel, R.; El-Wakil, N.A.; Dufresne, A.; Elkasabgy, N.A. Nanocellulose: From an agricultural waste to a valuable pharmaceutical ingredient. Int. J. Biol. Macromol. 2020, 163, 1579-1590. [CrossRef]

51. Cortesi, R.; Quattrucci, A.; Esposito, E.; Mazzaglia, A.; Balestra, G.M. Natural antimicrobials in spray-dried microparticles based on cellulose derivatives as potential eco-compatible agrochemicals. J. Plant Dis. Prot. 2017, 124, 269-278. [CrossRef]

52. Yang, W.; Fortunati, E.; Dominici, F.; Giovanale, G.; Mazzaglia, A.; Balestra, G.M.; Kenny, J.M.; Puglia, D. Synergic effect of cellulose and lignin nanostructures in PLA based systems for food antibacterial packaging. Eur. Polym. J. 2016, 79, 1-12. [CrossRef]

53. Fortunati, E.; Rescignano, N.; Botticella, E.; La Fiandra, D.; Renzi, M.; Mazzaglia, A.; Torre, L.; Kenny, J.M.; Balestra, G.M. Effect of poly(DL-lactide-co-glycolide) nanoparticles or cellulose nanocrystals-based formulations on Pseudomonas syringae pv. tomato (Pst) and tomato plant development. J. Plant Dis. Prot. 2016, 123, 301-310. [CrossRef]

54. Rostamabadi, H.; Falsafi, S.R.; Jafari, S.M. Starch-based nanocarriers as cutting-edge natural cargos for nutraceutical delivery. Trends Food Sci. Technol. 2019, 88, 397-415. [CrossRef]

55. Dureja, H.; Khatakb, S.; Khatakc, M.K. Amylose Rich Starch as an Aqueous Based Pharmaceutical Coating Material—Review. Int. J. Pharm. Sci. Drug Res. 2011, 3, 8-12.

56. Liu, Z.; Han, J.H. Film-forming Characteristics of Starches. J. Food Sci. 2005, 70, 31-36.

57. Feltre, G.; Almeida, F.S.; Sato, A.C.K.; Dacanal, G.C.; Hubinger, M.D. Alginate and corn starch mixed gels: Effect of gelatinization and amylose content on the properties and in vitro digestibility. Food Res. Int. 2020, 132, 109069. [CrossRef]

58. Hong, Y.; Liu, G.; Gu, Z. Recent advances of starch-based excipients used in extended-release tablets: A review. Drug Deliv. 2016, 23, 12-20. [CrossRef] [PubMed]

59. Lockyer, S.; Nugent, A.P. Health effects of resistant starch. Nutr. Bull. 2017, 42, 10-41. [CrossRef] 
60. Botticella, E.; Sestili, F.; Sparla, F.; Moscatello, S.; Marri, L.; Cuesta-Seijo, J.A.; Falini, G.; Battistelli, A.; Trost, P.; Lafiandra, D. Combining mutations at genes encoding key enzymes involved in starch synthesis affects the amylose content, carbohydrate allocation and hardness in the wheat grain. Plant Biotechnol. J. 2018, 16, 1723-1734. [CrossRef]

61. Cranston, E.D.; Gray, D.G. Morphological and optical characterization of polyelectrolyte multilayers incorporating nanocrystalline cellulose. Biomacromolecules 2006, 7, 2522-2530. [CrossRef] [PubMed]

62. Sparla, F.; Falini, G.; Botticella, E.; Pirone, C.; Talamè, V.; Bovina, R.; Salvi, S.; Tuberosa, R.; Sestili, F.; Trost, P. New starch phenotypes produced by TILLING in barley. PLoS ONE 2014, 9, e107779. [CrossRef] [PubMed]

63. Chrastil, J. Improved colorimetric determination of amylose in starches or flours. Carbohydr. Res. 1987, 159, 154-158. [CrossRef]

64. Cazorla, F.M.; Arrebola, E.; Sesma, A.; Pérez-García, A.; Codina, J.C.; Murillo, J.; De Vicente, A. Copper resistance in Pseudomonas syringae strains isolated from mango is encoded mainly by plasmids. Phytopathology 2002, 92, 909-916. [CrossRef] [PubMed]

65. King, E.O.; Ward, M.K.; Raney, D.E. Two simple media for the demonstration of pyocyanin and fluorescin. J. Lab. Clin. Med. 1954. [CrossRef]

66. Uppalapati, S.R.; Ishiga, Y.; Wangdi, T.; Urbanczyk-Wochniak, E.; Ishiga, T.; Mysore, K.S.; Bender, C.L. Pathogenicity of Pseudomonas syringae pv. tomato on tomato seedlings: Phenotypic and gene expression analyses of the virulence function of coronatine. Mol. Plant Microbe Interact. 2008, 21, 383-395. [CrossRef]

67. Canzoniere, P.; Francesconi, S.; Giovando, S.; Balestra, G.M. Antibacterial activity of tannins towards Pseudomonas syringae pv. tomato, and their potential as biostimulants on tomato plants. Phytopathol. Mediterr. 2021, 60, 23-36. [CrossRef]

68. Mojumdar, A.; Upadhyay, A.K.; Raina, V.; Ray, L. A simple and rapid colorimetric method for the estimation of chitosan produced by microbial degradation of chitin waste. J. Microbiol. Methods 2019, 158, 66-70. [CrossRef]

69. Zgoda, J.R.; Porter, J.R. A convenient microdilution method for screening natural products against bacteria and fungi. Pharm. Biol. 2001, 39, 221-225. [CrossRef]

70. Giacometti, A.; Cirioni, O.; Barchiesi, F.; Del Prete, M.S.; Fortuna, M.; Caselli, F.; Scalise, G. In vitro susceptibility tests for cationic peptides: Comparison of broth microdilution methods for bacteria that grow aerobically. Antimicrob. Agents Chemother. 2000, 44, 1694-1696. [CrossRef]

71. Gao, J.-C.; Guo, G.-J.; Guo, Y.-M. Measuring Plant Leaf Area by Scanner and ImageJ Software. China Veg. 2011, 1, 73-77.

72. Cerovic, Z.G.; Masdoumier, G.; Ghozlen, N.B.; Latouche, G. A new optical leaf-clip meter for simultaneous non-destructive assessment of leaf chlorophyll and epidermal flavonoids. Physiol. Plant. 2012, 146, 251-260. [CrossRef]

73. Li, B.; Shan, C.L.; Ge, M.Y.; Wang, L.; Fang, Y.; Wang, Y.L.; Xie, G.L.; Sun, G.C. Antibacterial mechanism of chitosan and its applications in protection of plant from bacterial disease. Asian J. Chem. 2013, 25, 10033-10036. [CrossRef]

74. Cheung, R.C.F.; Ng, T.B.; Wong, J.H.; Chan, W.Y. Chitosan: An Update on Potential Biomedical and Pharmaceutical Applications. Mar. Drugs. 2015, 13, 5156-5186. [CrossRef] [PubMed]

75. Martinez, L.R.; Mihu, M.R.; Han, G.; Frases, S.; Cordero, J.B.; Casadevall, A.; Friedman, A.J.; Friedman, J.M.; Nosanchuk, J.D. The Use of Chitosan to Damage Cryptococcus. Biomaterials. 2010, 31, 669-679. [CrossRef]

76. Pasquantonio, G.; Greco, C.; Prenna, M.; Ripa, C.; Vitali, L.A.; Petrelli, D.; Di Luca, M.C.; Ripa, S. Antibacterial activity and anti-biofilm effect of chitosan against strains of Streptococcus mutans isolated in dental plaque. Int. J. Immunopathol. Pharmacol. 2008, 21, 993-997. [CrossRef]

77. Khan, F.; Pham, D.T.N.; Oloketuyi, S.F.; Manivasagan, P.; Oh, J.; Kim, Y.M. Chitosan and their derivatives: Antibiofilm drugs against pathogenic bacteria. Colloids Surf. B Biointerfaces 2020, 185, 110627. [CrossRef]

78. Goy, R.C.; De Britto, D.; Assis, O.B.G. A review of the antimicrobial activity of chitosan. Polimeros 2009, 19, 241-247. [CrossRef]

79. Malveau, C.; Baille, W.E.; Zhu, X.X.; Marchessault, R.H. NMR imaging of high-amylose starch tablets. 2. Effect of tablet size. Biomacromolecules 2002, 3, 1249-1254. [CrossRef] [PubMed]

80. Onofre, F.; Wang, Y.J.; Mauromoustakos, A. Effects of structure and modification on sustained release properties of starches. Carbohydr. Polym. 2009, 76, 541-547. [CrossRef]

81. Xin, X.F.; Kvitko, B.; He, S.Y. Pseudomonas syringae: What it takes to be a pathogen. Nat. Rev. Microbiol. 2018, 16, 316-328. [CrossRef]

82. Rouse, D.I.; Nordheim, E.V.; Hirano, S.S.; Upper, C.D. A Model Relating the Probability of Foliar Disease Incidence to the Population Frequencies of Bacterial Plant Pathogens. Phytopathology 1985, 75, 505. [CrossRef]

83. El Hadrami, A.; Adam, L.R.; El Hadrami, I.; Daayf, F. Chitosan in plant protection. Mar. Drugs 2010, 8, 968-987. [CrossRef] [PubMed]

84. Katiyar, D.; Hemantaranjan, A.; Singh, B. Chitosan as a promising natural compound to enhance potential physiological responses in plant: A review. Indian J. Plant Physiol. 2015, 20, 1-9. [CrossRef]

85. Amborabé, B.E.; Bonmort, J.; Fleurat-Lessard, P.; Roblin, G. Early events induced by chitosan on plant cells. J. Exp. Bot. 2008, 59, 2317-2324. [CrossRef] [PubMed] 